\title{
Molecular Diagnosis of Medical Viruses
}

\author{
Rodney M. Ratcliff ${ }^{*}$, Grace Chang ${ }^{1}$, TuckWeng \\ Kok $^{1}$, and Theo P. Sloots ${ }^{2}$
}

${ }^{1}$ Infectious Diseases Laboratories, Institute of Medical and Veterinary Science, Frome Road, Adelaide, South Australia

${ }^{2}$ Clinical Virology Research Unit, Sir Albert Sakzewski Virus Research Center, Royal Children's Hospital and Health Service District, and Clinical Medical Virology Center, University of Queensland, Queensland, Australia

\begin{abstract}
The diagnosis of infectious diseases has been revolutionized by the development of molecular techniques, foremost with the applications of the polymerase chain reaction ( $\mathrm{PCR})$. The achievable high sensitivity and ease with which the method can be used to detect any known genetic sequence have led to its wide application in the life sciences. More recently, real-time PCR assays have provided additional major contributions, with the inclusion of an additional fluorescent probe detection system resulting in an increase in sensitivity over conventional PCR, the ability to confirm the amplification product and to quantitate the target concentration. Further, nucleotide sequence analysis of the amplification products has facilitated epidemiological studies of infectious disease outbreaks, and the monitoring of treatment outcomes for infections, in particular with viruses which mutate at high frequency. This review discusses the applications of qualitative and quantitative real-time PCR, nested PCR, multiplex PCR, nucleotide sequence analysis of amplified products and quality assurance with nucleic acid testing (NAT) in diagnostic laboratories.
\end{abstract}

\section{Introduction}

As with most bioscience disciplines, the diagnosis of human virological disease has been revolutionized by the development of molecular techniques. While this influence is now well over a decade old, the impact remains ongoing and the transition far from complete. Although various molecular techniques have been available for decades, it has only been in recent years that the technologies have matured sufficiently to make their diagnostic use viable. Foremost has been the development of real-time PCR, combining product detection and confirmation using very sensitive hybridisation probes, with target quantitation if desired, in a very rapid assay. Gene sequencing has additionally made a significant contribution. The combination of economical and rapid sequencing chemistries, computer-based phylogenetic analysis software and electronic interrogation of Internetaccessible gene sequence databases, has facilitated the use of molecular systematics to directly assist patient management, both for individual patients as in

*For correspondence: rod.ratcliff@imvs.sa.gov.au drug resistance testing, and within the community for the epidemiological analysis of infectious outbreaks. The scope of this review does not allow an exhaustive analysis of the molecular techniques available or in use for the detection of all medically important viruses. However, it is vital to first concentrate on the universal issue of assuring result accuracy, without which any test is meaningless. This will be followed by specific representative examples illustrating the use of molecular techniques for the diagnosis and management of human virological diseases.

\section{Result quality assurance}

Result quality is paramount and achievable only when all aspects of the test procedure are satisfactorily understood. This begins with the design, development and validation of the test for the range of specimen types, collection conditions and sample quality for which the test is expected to function (Table 1). These performance criteria are predominantly provided for commercial test kits but for in-house tests each aspect must be assessed in detail and the validation analyses documented before the use of such tests is valid. Once a test is implemented, irrespective of the source of the test, the ongoing performance must be carefully monitored, and problems documented, to ensure result quality is maintained. Laboratory design and staff competency also play crucial roles (Table 1 ). Typically quality assurance issues are detailed in national standards and guidelines for which compliance is obligatory to achieve good laboratory practice, and frequently mandated to achieve legislated accreditation.

\section{The causes of false results}

Each assay batch must contain adequate positive and negative controls to confirm test performance. They need to be chosen to ensure the validity of each and every step; nucleic acid extraction, preparation of reagent master-mixes, aliquoting of nucleic acid, amplification and detection. The inclusion of weakly positive control material, where the concentration of nucleic acid is just above the limit of detection, should be used to assess the performance of the whole test procedure, including extraction, to ensure test sensitivity is maintained for each batch. A negative patient sample is also essential, and should always be processed last at each step, after any positive controls, to ensure sample contamination is not occurring. Additional negative controls should be spaced throughout large assay batches. A master-mix negative water control, not opened during the aliquoting of nucleic acid, is also advised to confirm the mastermix is uncontaminated. Even when the performance of controls is adequate, clusters of positive results, especially following a strongly positive sample, should be 


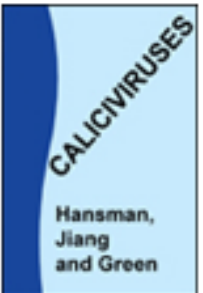

EPSTEIN

BARR

VIRUS

Erles.

Robertson

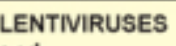

and

MACROPHAGES

Moira Desport

\section{MICROBIAL POPULATION GENETICS}

Jianping $X u$

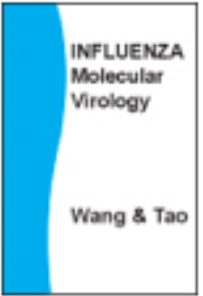

RNA INTERFERENCE AND VIRUSES

Mouel Angel Martinez

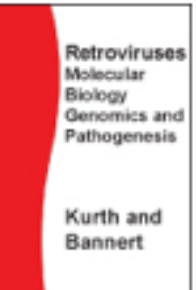

DENGUE URUS RESEARCH

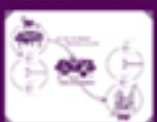

Edited by: Grant S. Hansman, Jason Jiang and Kim Y. Green

ISBN: 978-1-904455-63-9

Publisher: Caister Academic Press

Publication Date: April 2010

Cover: Hardback

\section{Epstein-Barr Virus: Latency and Transformation Buy now!}

Edited by: Erle S. Robertson

ISBN: 978-1-904455-62-2

Publisher: Caister Academic Press

Publication Date: April 2010

Cover: Hardback

\section{Lentiviruses and Macrophages: Molecular and Cellular Interactions Buy now!}

Edited by: Moira Desport

ISBN: 978-1-904455-60-8

Publisher: Caister Academic Press

Publication Date: March 2010

Cover: Hardback

\section{Microblal Population Genetics Buy nowl}

Edited by: Jianping $X u$

ISBN: $978-1-904455-59-2$

Publisher: Caister Academic Press

Publication Date: March 2010

Cover: Hardback

Covers the population genetics and epidemiology of human viral pathogens

\section{Influenza: Molecular Virology Buy now!}

Edited by: Qinghua Wang and Yizhi Jane Tao

ISBN: 978-1-904455-57-8

Publisher: Caister Academic Press

Publication Date: February 2010

Cover: Hardback

\section{RNA Interference and Viruses: Current Innovations and Future Trends Buy now!}

Edited by: Miguel Angel Martínez

ISBN: 978-1-904455-56-1

Publisher: Caister Academic Press

Publication Date: February 2010

Cover: Hardback

\section{Retroviruses: Molecular Blology, Genomics and Pathogenesis Buy now!}

Edited by: Reinhard Kurth and Norbert Bannert

ISBN: 978-1-904455-55-4

Publisher: Caister Academic Press

Publication Date: January 2010

Cover: Hardback

\section{Frontiers in Denque Virus Research Buy now!}

Edited by: Kathryn A. Hanley and Scott C. Weaver

ISBN: 978-1-904455-50-9

Publisher: Caister Academic Press

Publication Date: January 2010

Cover: Hardback 


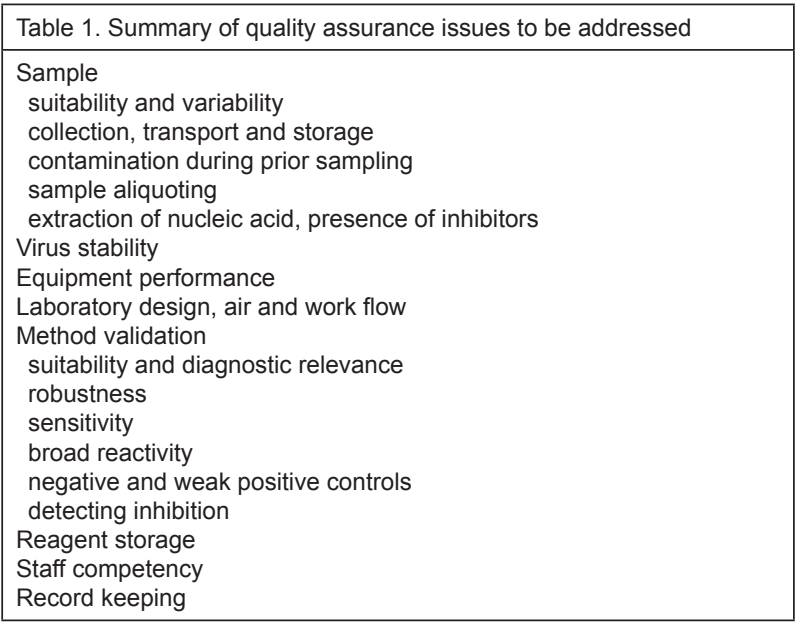

viewed with suspicion until the suspect samples can be re-extracted and retested to confirm the result.

\section{Contamination}

The elimination of false results requires an understanding of their causes (Table 2). With PCR-based tests, where the same methods are performed repeatedly, the potential for contamination of new tests with amplified product (amplicon) from previous amplifications of the same target sequence poses by far the greatest risk, and is the commonest cause of false positive results. It is essential that the functions of (a) PCR reagent storage and master mix preparation, (b) nucleic acid extraction, (c) addition of nucleic acid to PCR mixes, and (d) PCR amplification and post-PCR manipulation, e.g. running of gels, sequencing or cloning of products, are physically separated, with independent airflows, to minimize contamination. Ideally, each should be performed in physically separated rooms. A unidirectional workflow from one function to the next is essential to eliminate the risk of contamination to set up areas with previously amplified product. Each area must have its own dedicated pipettors, equipment, consumables and staff personal protective equipment, e.g. lab gowns/coats and gloves. Staff must be well trained and employ scrupulous sterile technique. If racks need to be returned against the unidirectional workflow, they must first be disinfected in $2 \%$ sodium hypochlorite

\begin{tabular}{|l|}
\hline Table 2. Summary of the causes of false results \\
\hline False positive results \\
\hline Contamination from: \\
- Prior sample testing by autoanalysers \\
- Amplicons from previous amplifications of the same target \\
Aliquoting errors; sample or reagents \\
Transcription errors during resulting and record keeping \\
\hline The cause of false negative results \\
\hline Presence of inhibitors in the sample \\
Degraded samples \\
Strain diversity reducion \\
- Primer target homology \\
- Probe target homology (real-time PCR) \\
Degraded reagents \\
Malfunctioning equipment \\
Aliquoting errors; sample or reagents \\
Transcription errors during resulting and record keeping \\
\hline
\end{tabular}

or the equivalent for 4 hours. PCR-certified filtered tips should be used at all stages, and reagent, sample and PCR tubes should be kept capped, only opening when specifically required. The use of ganged cap strips should be avoided, as the latter requirement cannot be achieved. Ganged strips of tubes with individually attached caps are available and should be preferred. Post-use wiping down of work areas and pipettes with $2 \%$ sodium hypochlorite disinfectants and irradiation of the work areas with UV light is also good practice. The use of a biohazard hood is advised for steps 1 to 3 above, both as a protection from potentially infectious agents for the operator and to reduce the risk of sample contamination. While the HEPA filters in such cabinets are typically rated to $0.3 \mu \mathrm{m}$, smaller particles such as many viruses and nucleic acid molecules are also likely to be efficiently retained. Viruses are often aggregated, attached or contained within larger particles such as cells, and molecular interactions such as electrostatic attraction and Brownian motion, rather than size exclusion, are likely to efficiently retain nucleic acid molecules. However, such cabinets used for manipulating post-amplification products, e.g. during two-tube nested amplification, should be externally vented, to ensure that any amplicons which pass through the filters into the exhaust are not recirculated. The use of dUTP to replace dTTP in the PCR master mix, and the incorporation of Uracil-DNA Glycosylase (UNG) to degrade previously amplified uracil-containing contaminating amplicons, a method commonly incorporated in commercial kits, should also be considered to eliminate contamination although it is only effective when the level of contamination is low. However, residual UNG activity may remain after amplification, so PCR samples should be stored at $20^{\circ} \mathrm{C}$ if immediate analysis of the product is not possible. In addition, the use of dUTP and UNG is problematic for one-step RT-PCR, necessitating the use of a heatstable reverse transcriptase, active above $60^{\circ} \mathrm{C}$, to prevent the CDNA being degraded before PCR. Such RT-PCR requirements and conditions may reduce assay sensitivity.

Samples submitted to a diagnostic laboratory are frequently used for multiple tests. Biochemical or haematological tests processed by auto-analysers are typically performed first before the specimen is forwarded for virological testing. Such auto-analysers can crosscontaminate specimens during injection sampling. Setting aside an aliquot specifically for molecular testing resolves this problem, but introduces the risk of transcription and aliquoting errors, and specimens can be too limited for adequate splitting.

\section{Inhibition}

The presence of inhibitors to the amplification reaction, such as haemoglobin, lactoferrin and bile salts, within the sample is the major cause of false negative results (AlSoud et al., 2005; Al-Soud and Radstrom, 2001). Most commercial nucleic acid extraction systems incorporating a spin or vacuum column allow for efficient removal of inhibitors because the nucleic acid trapped in the silicagel membrane can be very effectively washed before elution. Similarly, methods incorporating magnetic bead techniques to capture and retain nucleic acid also 
achieve high recovery and purity rates. However, some samples will remain inhibitory and such samples need to be identified with the use of effective inhibition controls. One method is to assay for the presence of nucleic acid either intrinsically present in the sample or added (either virus particles or nucleic acid) as a control, which will be co-extracted so as to act both as an extraction and an inhibition control. Such control nucleic acid should be present only at levels close to the limit of the assay, to provide a realistic assessment of the presence of inhibitors. Due to the potential reduction in amplification sensitivity when combining both a separate inhibition control target and the test target in a multiplex reaction, we prefer to perform a duplicate inhibition control for each sample spiked with the low positive control. However, such multiplex, simultaneous testing of test and inhibition control targets may be acceptable if maximum sensitivity is not required. Inhibition controls in some specimen types can be forgone if the rate of inhibition has been confirmed as very low e.g. CSF. Samples containing inhibitors can be further treated with chelating agents such as Chelex 100 (Bio-Rad Laboratories, Hercules, CA, USA) chelating resin, for removal of divalent metal cations or diluted until the inhibition is no longer detectable, mindful that these steps will reduce the test sensitivity. During the development phase, if inhibition is a problem because of the nature of the samples being tested e.g. faeces, the inclusion of amplification facilitators such as bovine serum albumin and betaine to minimize inhibition problems should be considered (Abu Al-Soud and Radstrom, 2000). In addition, some polymerases may better tolerate the presence of inhibitors than others (Al-Soud et al., 2005).

\section{Target homology}

Primer and probe target sites are ideally chosen from the regions of the genome conserved among the strains of the virus to be detected. Often this is to functionally constrained regions within protein-encoding non-structural genes, to ensure broad reactivity of the test for all wild strains of the virus. However, this is not always possible. RNA viruses exhibit considerable diversity among wild strains. For instance, although known strain diversity at the target site is accommodated within the primer and probe design, the genetic diversity of some viruses, such as caliciviruses and HIV, exceeds the ability of the test to detect all strains without loss of sensitivity. Reducing the annealing temperature may allow satisfactory priming even in the presence of several target/primer nucleotide mismatches, unless close to or at the $3^{\prime}$ end of the primer. However, this does increase the likelihood of non-specific amplification, so validity of any product must be confirmed. The incorporation of 'universal' nucleotide bases, such as inosine, can effectively accommodate extreme strain diversity at particular primer or probe sites but the results are variable and sensitivity can be compromized. Our experience suggests limiting the use of inosine to as few sites as possible and certainly no more than three separated primer sites not close to the $3^{\prime}$ end of the primer. In addition, some polymerases appear to exhibit better tolerance to the presence of inosine than others and amplification efficiency may be enhanced if the extension temperature is reduced to as low as $60^{\circ} \mathrm{C}$. Sequencing such product can be problematic, as inosine-containing primers may inadequately prime dye terminator cycle sequencing reactions.

Where fluorescent probes are being used to detect the presence of amplification products, it is possible that amplification has occurred but sequence variation in the amplicon prevents probe hybridisation. During the test development phase, when the method is being compared with other tests, but also for critical specimens, anomalous negative results should be checked using gel electrophoresis and UV-illuminated ethidium bromide staining. The sequence of the probe target of any amplicons present can then be characterized to ascertain and correct the cause of the lack of hybridisation in a redesigned probe.

Just as specificity is the great advantage of PCR, it is also its Achilles heal, in that unknown strain diversity will remain undetected. For viruses where sequence diversity among strains is high, the design of primers and probes needs to be constantly reviewed in the light of newly published sequences. Even as few as one or two mismatches in a primer can reduce amplification efficiency, and within a fluorescent probe, reduce or eliminate the strength of the fluorescence signal. The latter is especially true for DNA probes conjugated to other DNA binders such as minor groove binding (MGB) groups to assist in probe binding. This shortens the DNA sequence required for $3^{\prime}-M G B$ probes to achieve the same melting temperature $\left(T_{\mathrm{m}}\right)$ increasing the specificity of the probe (Kutyavin et al., 2000). While this is highly advantageous to increase assay specificity, such probes are also more vulnerable to mismatches from viral strain sequence diversity. Consequently, a false negative result due to strain diversity is always possible and important clinically relevant specimens should be examined by alternative methods.

\section{Poorly maintained equipment and reagents}

The optimal performance of molecular tests is often restricted to narrow limits in temperature and reagent volumes, and poorly maintained equipment can introduce sufficient errors for the test to fail. The performance and accuracy of all equipment such as pipettors and theromocyclers must be routinely checked to ensure they are performing within specifications. While controls are included within each test batch as an early warning that an error has occurred, it is possible for malfunctioning equipment to remain undetected if this is the only check of valid performance. For instance, peltier-type thermocyclers can have more than one peltier cell per heating block and should one of these peltier cells fail, that zone of the block will not achieve the correct cycle temperatures. Furthermore, the performance failure may go undetected if the control samples happen to be constantly located in the normal functioning regions of the block. For this reason all equipment must be maintained and performance regularly checked and documented in line with the manufacturer's recommendations and specifications.

Similarly, poor reagent storage protocols, especially where such reagents are subject to repeated freeze-thaw, will quickly reduce enzyme potency, decreasing assay 
sensitivity and causing false negatives. RNA is especially fragile and rapidly degraded by ubiquitously present RNAses. If a weakly positive control is not included in each assay batch, the reduced sensitivity may remain undetected. The assay protocols should detail how reagents are to be aliquoted, stored and used to prevent degradation of reagent potency.

\section{Collection, transport, storage and extraction of samples}

Even a well performing assay will not resurrect the loss of sample integrity due to inadequate collection or handling of the sample. Protocols should be devised to describe adequate performance of each step of sample handling, from acceptable patient samples and collection techniques, transport to the laboratory, and storage of the sample and extracted nucleic acid prior to testing. The latter is especially important for RNA, which is easily sheared during freeze-thaw cycles and subject to degradation by nucleases. Sub-optimal performance of any of these specimen collection or handling steps may result in falsely negative tests. The performance of the assay should be validated for such protocols, and specimens rejected when they don't comply.

\section{Assay sensitivity}

One of the significant advantages of molecular assays is the high degree of sensitivity; detection of less than 10 copies even for RNA targets can be achieved, if the assay is well designed and the sample integrity is maintained throughout collection, transport, extraction and storage. In addition, while these latter issues have been rightly emphasized, molecular tests can detect the presence of nucleic acid when the virus is no longer viable, perhaps the result of patient therapy or after prolonged sample storage. The latter is especially useful for retrospective analysis of undiagnosed disease after new infectious agents are discovered. However, the increased sensitivity which can be achieved with such tests and the ability to detect non-viable infectious agents may require a careful assessment of result interpretation, e.g. for viruses which may be carried in low numbers asymptomatically, or posttherapy.

Molecular assays requiring genetic amplification based on the polymerase chain reaction (PCR) now dominate the molecular detection of human viruses. Such assays are rapid, sensitive and easily adapted to target any known genetic sequence. The inclusion of a prior reverse transcription (RT) step facilitates the detection of RNA viruses. Sufficient sensitivity can be achieved in a single reaction of 25-40 cycles for many diagnostic tests where the ability to detect very low numbers of virus particles is not required. Sensitivity can be increased by either (a) a nested reaction, or (b) real-time fluorescent assay. In the former, the additional cycles can increase sensitivity by at least 100 -fold. A similar improvement in sensitivity is achieved in the latter, due to the increases sensitivity attained by the fluorescent detection system. The latter requires more expensive reagents and equipment, but also can offer product confirmation and quantitation. Three examples of PCR are outlined; nested RT-PCR, real-time PCR and quantitative PCR.

\section{Nested RT-PCR for the detection and typing of norovirus}

Caliciviruses are a major cause of acute gastroenteritis, and the species Norovirus (previously Norwalk-like virus) is the most common cause of such disease associated with outbreaks (Glass et al., 2000). Being RNA viruses, the genome diversity among norovirus strains challenges the broad reactivity of any test to detect them. As antigenbased ELISA tests were unreliable, it was not until the early 90 s and the development of RT-PCR tests, that the significance of noroviruses could be understood. The genome of approximately $7500 \mathrm{bp}$ encodes three open reading frames (ORF). The first, ORF-1 contains the nonstructural genes which encode a helicase, a protease and a polymerase. The functionally constrained regions of the latter, designated Regions $\mathrm{A}$ and $\mathrm{B}$, are the most common targets chosen for RT-PCR assays to detect their presence in stool samples (Ando et al., 2000; Fankhauser et al., 2002; Jiang et al., 1999). More recently, real-time assays targeting the $3^{\prime}$-end of the ORF-1 have been developed (Kageyama et al., 2003, Trujillo et al., 2006). To detect the very low numbers of virions potentially present in the faeces of patients in early or late infection we designed a closed-system nested RT-PCR method. While singletube nested methods have been published (Olmos et al., 1999; Wolff et al., 1995), they often incorporate awkward and unwieldy mechanisms to contain the nested reagents during primary amplification. We ascertained that the nested reagents could be stably contained in the tube cap as a simple hanging drop supported by the innate surface tension of the reagents, requiring only a short microfuge centrifugation at the end of the primary amplification to combine the reagents for the nested reaction (Ratcliff et al., 2002). Because a heated lid cannot be used during the primary amplification, the primary reagents must be overlaid with paraffin oil to prevent evaporation. Comparative tests established that this nested 'hangingdrop' single-tube RT-PCR method increased sensitivity by at least 100-fold (see Fig. 1), similar to two-tube nested methods, but without the significant contamination risks normally associated with such nested reactions. In addition, having the extra set of primers can benefit the rate of detection of genetically variable viruses. Where in a single amplification, a variable target at one primer site will typically prevent amplification, in this nested method it is possible that product may still be amplified by combinations of the other primers present. However, the primary antisense (reverse) primer must be homologous, as it primes the RT step for one-tube reactions. Our experience with this method highlights the need to continually assess test performance. After months of reliable performance, a loss of sensitivity was detected based on the performance of the controls. Analysis of the assay revealed that the AMV reverse transcriptase in the primary reaction was now inhibitory to the polymerase used in the nested reaction. Neither manufacturer reported any modification of these enzymes. Satisfactory resolution of the problem was achieved by diluting the AMV reverse transcriptase to 0.05 Units per reaction and using Amplitaq Gold (Applied Biosystems, Inc. [ABI], Foster City, Calif.) and GeneAmp $10 \times$ Buffer II $(\mathrm{ABI})$ in both primary and nested reactions as per the manufacturer's specifications. Although the 


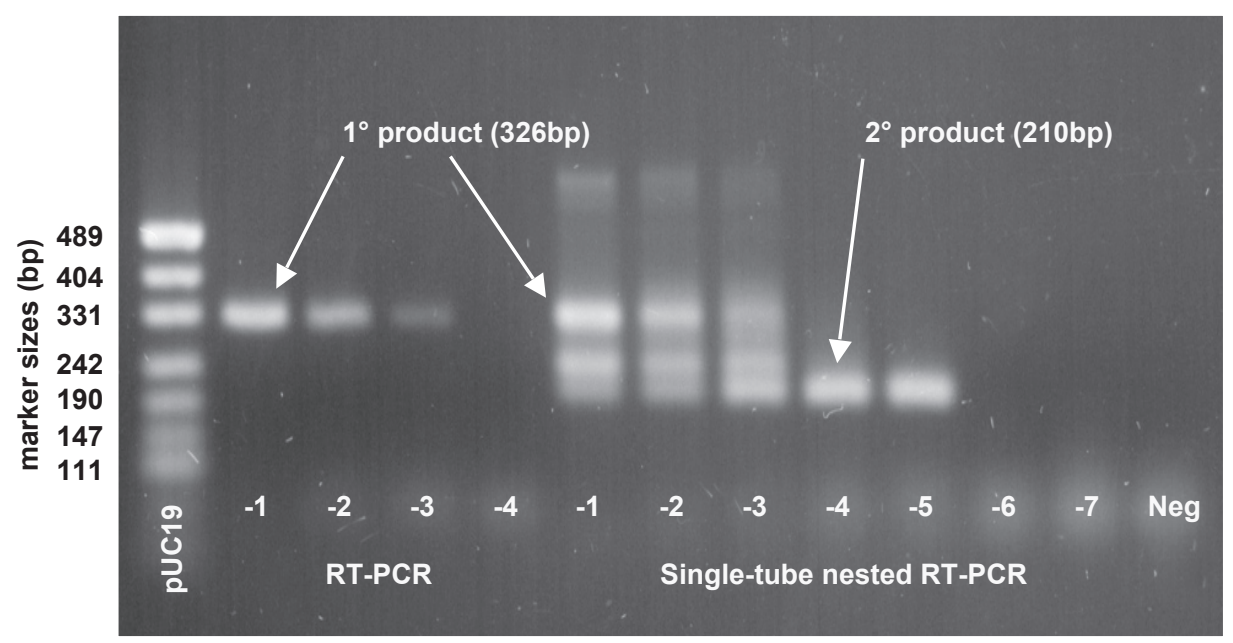

Fig. 1. Typical amplification patterns for ten-fold serially diluted faecal RNA extracts containing Norovirus genotype 2 using (a) RT-PCR (lanes $2-5$ ) and (b) one-tube "hanging drop" nested RT-PCR (lanes 6-12), showing a 100-fold increase in sensitivity with the latter method. Reproduced with kind permission (American Society for Microbiology Journals Department) from Ratcliff et al., 2002. RT-PCR (a) single amplification with the primary amplification reagents produces a $326 \mathrm{bp}$ product. Single-tube nested RT-PCR (b) sequentially amplifying for primary and secondary nested products, produces the primary amplification product at high target copy number, and the additional $210 \mathrm{bp}$ nested product at low target copy number. Lanes are marked with the RNA extract dilution; $-1=10^{-1}$ etc. Also note in the latter method the presence of an intermediate-length product produced by amplification from inner and outer primer pairs.

concentration of AMV is very low, the polymerase activity is uninhibited and test sensitivity is equivalent to that previously published.

\section{Real-time PCR}

The advantages of a rapid assay time, and an inbuilt detection system which can offer product confirmation and quantitation, with an electronic result output which lends itself to high through-put electronic reporting typically required in a diagnostic laboratory, has guaranteed that real-time PCR will make a major contribution to the diagnosis of infectious disease. Most conventional PCRbased testing formats involve multiple steps of varying complexity and open reaction systems, which increase the risk for sample contamination by extraneous amplified DNA (amplicons). Real-time PCR combines PCR amplification with detection of the amplification product in the same closed system, resulting in a significantly reduced risk of carry-over contamination. In addition, realtime PCR instruments typically cycle the temperatures more rapidly than conventional thermocyclers, and offer a much broader dynamic range of up to $10^{7}$-fold, compared to $10^{3}$-fold in conventional PCR, because of the increased sensitivity of the fluorescent detection system.

\section{Real-time PCR technology}

Real-time PCR technology is based on the detection and quantitation of a fluorescent reporter (Lee et al., 1993; Livak et al., 1995), which increases in direct proportion to the amount of PCR product in the reaction. The higher the starting copy number of the nucleic acid target, the sooner a significant increase in fluorescence is observed. Fluorescent chemistries commonly used include nonspecific compounds such as the DNA intercalating dyes SYBR $®$ green (Schneeberger et al., 1995) and Syto9 (Monis et al., 2005) or sequence-specific oligoprobes that carry a donor and acceptor fluorophor and employ Fluorescent Resonance Energy Transfer (FRET) (Hiyoshi and Hosoi, 1994). While some product confirmation can be achieved with non-specific fluorescent dyes by performing denaturation (melting) curve analysis at the completion of the amplification, in practice, our experience has been that the specific approach yields better results for the detection of infectious agents in clinical specimens, and particularly so in the determination of pathogen load. Commonly, two fluorescence-monitoring systems for DNA amplification using specific oligoprobes are used. These are (a) dual-labelled probes; and (b) single-labelled hybridising probes.

Dual-labelled probes include TaqMan probes (Heid et al., 1996), molecular beacons (Mhlanga and Malmberg, 2001) and scorpion probes (Saha et al., 2001; see also Svanvik et al., 2000 for light-up probes). TaqMan probes were among the first to be applied in real-time PCR, and consist of oligonucleotides that contain a fluorescent dye at the 5' base, and a quenching dye (usually TAMRA) on the 3' base. On excitation by an incident wavelength, the fluorescent dye transfers energy to the nearby quenching dye molecule rather than releasing fluorescence. TaqMan probes are designed to anneal to a complementary sequence on a PCR product, and the close proximity of the reporter and quencher prevents emission of any fluorescence while the probe is intact. As the polymerase replicates the template on which a TaqMan probe is bound, its 5' exonuclease activity hydrolyses the probe (Holland et al., 1991). This separates the fluorescent and quencher dyes resulting in the emission of fluorescence, which increases in each cycle proportional to the rate of probe cleavage. Accumulation of PCR products is detected by monitoring the increase in fluorescence of the reporter dye. As mentioned previously, 3'-MGB (Kutyavin et al., 2000) and other conjugated binding assisting groups, 
have enabled increased specificity with a shorter probe such that single-base allelic variation within the probe target binding site is possible with well designed probes.

Single-labelled hybridisation probes (or HybProbes) are most commonly used with the LightCycler instrument (Roche Diagnostics, Basel, Switzerland) (Wittwer et al., 1997). This technology uses two fluorescently labelled oligonucleotides; a donor probe labelled with fluorescent dye at the 3 ' end and an acceptor probe labelled at the 5' end, which absorbs resonance energy from the donor probe via FRET. Fluorescence by the acceptor probe will only occur when both the donor probe and the acceptor probe have annealed to the amplification product in close proximity to each other, providing a measure of amplification product formation.

The process is non-destructive and reversible, with the melting temperature of the hybridisation complex being sequence dependent. Melting curve analysis of amplification products provides an extra element of specificity to the PCR, because sequence variation in probe target sites will result in a shift in the melting temperature. This may act as an important quality control feature that confirms PCR amplicons as the correct amplification product, and provides a simple and elegant method to genotype mutations, including single base mutations (Bernard et al., 1998; Lay and Wittwer, 1997). Melting curve analysis can be performed with FRET probes and molecular beacons, but not with hydrolysis (TaqMan) probes.

\section{Practical applications of real-time PCR in the diagnostic laboratory}

Review of the current literature shows that many diagnostic assays in the infectious diseases laboratory have been adapted to a real-time PCR format and this technology is now widely used for the detection of bacterial, viral and fungal pathogens. It has been particularly important in the rapid diagnosis of life-threatening viral diseases such as those caused by avian influenza (H5N1) (Whiley et al., 2005) or herpes simplex (herpes simplex encephalitis) (Whiley et al., 2004b). However, significant improvements have also been achieved in our laboratory in applying real-time PCR protocols for the detection of respiratory viruses, the human herpesviruses, enteroviruses, JC virus, BK virus, Bordetella pertussis, Mycoplasma pneumoniae, Chlamydia trachomatis, Neisseria gonorrhoea as well as Aspergillus fumigatus and Pneumocystis jiroveci (Whiley et al., 2004a; Whiley et al., 2001; Whiley et al., 2002). A comparison of these assays with conventional culturebased methods convincingly demonstrated greater sensitivity of the molecular assays.

\section{Quantitative real-time PCR}

The ability of real-time PCR to accurately quantify the viral load in clinical specimens has made a major contribution as it offers a direct measurement of active viraemia (Daar et al., 1991). It offers the possibility to determine the dynamics of viral proliferation; a higher viral load may correlate with disease progression and virus transmission (Kowala-Piaskowska et al., 2004; Mellors et al., 1996). The determination of viral load in plasma is particularly useful for monitoring the efficacy of antiviral therapy and distinguishes between latent and active infections. The results can be expressed in absolute terms with reference to quantified standards, or in relative terms compared to another target sequence present in the sample.

Many quantitative real-time PCR ( $\mathrm{PPCR}$ ) protocols for the detection of microbial targets have now been published and commercial assays are available for a number of clinically important viruses including human immunodeficiency virus (HIV) (Kumar et al., 2002; O'Doherty et al., 2002), hepatitis B (HBV) and C (HCV) viruses (Berger et al., 1998; Kamal et al., 2005; KowalaPiaskowska et al., 2004) and cytomegalovirus (CMV) (Boeckh and Boivin, 1998). However, the number of commercial assays available is still quite limited and this has led to the development and introduction of in-house real-time qPCR protocols.

\section{Viral load and the pitfalls of quantitative PCR}

In order to obtain meaningful results, it is important that the efficiency of the qPCR does not vary greatly due to minor differences between samples, and careful optimisation of the qPCR conditions must be performed. To ensure accuracy, a quantitation standard (QS) with known viral quantity (e.g. copy number) is incorporated into each sample, and carried through sample extraction, reverse transcription (RT-PCR), amplification, hybridisation and detection. The QS compensates for effects of inhibition and controls for the amplification process to ensure the accurate quantitation of viral DNA/RNA in each sample. Even so, other factors, inherent to the target organism, such as genome polymorphism (particularly in RNA viruses) can affect the results of both end-point PCR and qPCR.

\section{Current Commercial kits for viral load measurement}

- PCR/RT-PCR for quantifying DNA or RNA (e.g. Roche Cobas Amplicor Monitor [end-point] kits, dynamic range: $\mathrm{HCV}, 600-5 \times 10^{5} \mathrm{IU} / \mathrm{ml}$ and HIV, $50-1 \times 10^{6} \mathrm{copies} / \mathrm{ml}$; Roche Cobas Taqman (realtime) kits, dynamic range: $\mathrm{HCV}, 43-6.9 \times 10^{7} \mathrm{IU} / \mathrm{ml}$ and HIV, $40-1 \times 10^{7}$ copies $/ \mathrm{ml}$ ).

- Branched chain DNA signal amplification technology for quantifying viral DNA or RNA (e.g. Bayer Versant bDNA assays, dynamic range: $\mathrm{HCV}, 615$ to $7,690,000$ IU/ml and HIV, 50-500,000 HIV-1 RNA copies/ml). Viral DNA or RNA is hybridized to the microwell surface via capture probes. A set of target probes hybridize both the viral RNA and the pre-amplifier probes. The amplifier probe hybridizes to the pre-amplifier probe forming a branched DNA (bDNA) complex. The bound bDNA is incubated with an enzyme and then with a chemiluminescence substrate.

- Transcription mediated amplification (TMA) for quantifying DNA or RNA (e.g. Quest Heptimax HCV assay, dynamic range: $\left.5-8.3 \times 10^{7} \mathrm{IU} / \mathrm{ml}\right)$. A target nucleic acid amplification method that uses RNA transcription (RNA polymerase) and DNA synthesis (reverse transcriptase) to produce RNA amplicon from a target nucleic acid. TMA produces 100-1000 copies per cycle (RNA) rather than the two copies per cycle produced by PCR (DNA). 
- $\quad$ Nucleic acid sequence-based amplification (NASBA) for quantifying viral RNA (e.g. Biomerieux NucliSens EasyQ HIV-1 assay, dynamic range: $50-3 \times 10^{6} \mathrm{IU} /$ $\mathrm{ml}$ ). NASBA is a sensitive, isothermal, transcriptionbased amplification system designed specifically for the detection of RNA targets. RNA is extracted and bound to silica beads. Nucleic acid is amplified using specific primers. The amplified RNA is hybridized to capture probes attached to magnetic beads, and is detected by measuring electrochemiluminescence. The NucliSens EasyQ HIV-1 assay combines NASBA amplification with real-time detection using molecular beacons in a single step (Weusten et al., 2002).

- Hybrid capture signal amplification technology for quantifying viral DNA (e.g. Digene HC2 HBV DNA Test Plus, dynamic range: $\mathrm{HBV}, 1.42 \times 10^{5}$ to $1.7 \times 10^{9}$ copies/ml). Target DNA combines with specific RNA probes to create RNA:DNA hybrids. Multiple RNA: DNA hybrids are captured onto a solid phase coated with universal capture antibodies specific for RNA: DNA hybrids and detected with alkaline phosphatase and chemiluminescent dioxetane substrate.

Careful consideration needs to be given when choosing a quantitative assay for determining viral load. Commercial kits are usually validated using a large cohort of clinical samples. Development of in-house assays may be achieved if a properly structured validation procedure is implemented. However, regulatory requirements in some countries may restrict the diagnostic use of such in-house assays, e.g. in Australia for tests required to comply with the Therapeutic Goods Administration (TGA), such as for HIV and HCV.

\section{Issues affecting real-time PCR results}

It is important to recognize a number of issues that may impact on the performance of real-time PCR assays.

Firstly, sequence information available on public databases such as GenBank may be limited or may not accurately reflect sequence data for micro-organisms circulating in the local population. This was demonstrated in a real-time PCR assay for herpes simplex virus (HSV) published by Espy et al. (2000), which, when applied in our laboratory, incorrectly typed some HSV type 1 as HSV type 2 by melting curve analysis. The reason was that local strains of HSV type 1 differed in sequence from those used to validate the assay described by Espy et al., and this sequence variation resulted in a change in melting temperature consistent to that for HSV type 2 (Whiley and Sloots, 2005a).

Another important limitation of melting curve analysis is its inability to detect two viral types (or viral strains) using common primers, if both are present simultaneously in a single specimen. This was demonstrated in a real-time PCR to distinguish JC and BK viruses by melting curve analysis developed in our laboratory. Our results showed that the relative viral loads of JCV and BKV in a single sample need only differ by one log for the assay to fail in the detection of both viruses (Whiley and Sloots, 2005a). Similar observations were also made for specimens collected from patients dually infected with HSV1 and HSV2.
Finally, sequence variation may also have a significant impact upon the accuracy of viral qPCR assays. Recently, we examined the impact of sequence mismatches in the primer target sites on qPCR. The results showed that as few as two mismatches in the $3^{\prime}$ end of a single primer could introduce considerable error, underestimating viral load by up to 3 logs (Whiley and Sloots, 2005b). The overall impact this has on qPCR results is dependent on the conditions used in the assay and may hinge on the nucleotide composition of the primers, the PCR annealing temperature, the reaction mix composition and the specific nucleotides that are the subject of mismatch.

\section{Multiplex PCR}

Multiplex PCR refers to the use of different pairs of primers to simultaneously amplify multiple nucleic acid regions from a sample. The term multiplex originally referred to a cinema with several movies shown simultaneously. In this context, multiplex PCR is the simultaneous amplification of multiple selected target regions with visualisation of the amplified products by gel electrophoresis, real-time PCR or detection with the use of digoxigenin (DIG)-labelled dUTP and antibodies to DIG (Roche Diagnostics, Basel, Switzerland). The main advantage of using multiplex $\mathrm{PCR}$ is to minimize the number of separate reactions, for example to detect a range of pathogens in one specimen, sequence variations for pathogen strain identification and analysis of multiple mutations or polymorphisms in genetic studies. Other advantages include conservation of time, reagents and samples that are of limited volume. The first reported use of multiplex PCR was the simultaneous amplification of multiple loci in the human Duchenne muscular dystrophy gene (Chamberlain et al., 1988).

\section{Optimisation}

The design and development of multiplex PCR is similar to that used in conventional PCR with a pair of primers specific for a selected region of the target sequence. These include optimisation of reaction components viz. primer designs ( 20 nucleotides long and GC content of 40-60\% with matched $T_{m}$ values of $50-60^{\circ} \mathrm{C}$ ) concentrations of $\mathrm{Mg}^{2+}, \mathrm{dNTP}$, primers, annealing and extension conditions. The concentrations of $\mathrm{Mg}^{2+}$ and dNTP used are generally higher in a multiplex PCR. Although it may be assumed that it is useful to design primers with similar $T_{m}$ value, this may not necessarily yield similar annealing temperatures in the multiplex PCR. Similarly, primers with different $T_{m}$ values may not necessarily yield vastly different annealing temperatures, due to empirical determinations of $T_{m}$ values with different salt concentrations and assay conditions. Each of these reaction parameters needs to be titrated initially with matched primer pairs, in separate reactions, in order to determine optimal amplification efficiencies and detection sensitivities. This is then compared with the sensitivity of the multiplex PCR.

\section{Asymmetric conditions}

Having determined optimal PCR components and cycling conditions for each of the targets, in separate reactions, equimolar concentrations of primers can be used in the multiplex PCR. The optimal primer concentrations in the multiplex PCR would then be determined by subsequent 
titrations to compare sensitivities for each of the targets. The primer concentrations would need to be increased for the target that showed weak amplification signals in the multiplex PCR. The term asymmetric PCR is sometimes used loosely to refer to different optimal concentrations of forward and reverse primers for the matched pair. This may be a result of maintaining optimal total primer concentrations, as well as other components, in the multiplex PCR. Subsequent optimal conditions would then be determined for the other reaction components and cycling conditions, by comparing test sensitivities and specificities with the single primer pair PCR. It may be helpful to use the same thermal cycler for all optimisations with the single and multiplex PCR to minimize variations.

\section{Touchdown PCR}

Touchdown PCR is a useful approach for rapid determination of the optimal cycling conditions, particularly during the development of real-time multiplex PCR. Starting with an initial annealing temperature several degrees higher than the calculated $T_{m}$, the temperature is progressively decreased by steps of $0.5^{\circ} \mathrm{C}-2^{\circ} \mathrm{C}$ for one or two cycles per temperature increment, completing the amplification cycles at the lowest temperature increment. Subtracting 15-18 cycles (approximately the number of cycles for product to be detected in optimal conditions) from the cycle where the product is first detected $(\mathrm{Ct})$, will suggest the optimal annealing temperature range. This can be further evaluated with additional real-time PCR assays using fixed annealing temperatures.

\section{Buffers}

There are commercially available buffers and Taq DNA polymerase (e.g. HotStartTaq, Qiagen $\mathrm{GmbH}$, Hilden, Germany, and iQ Multiplex Powermix, Bio-Rad Laboratories, Hercules, CA, USA) that are prepared specifically for multiplex PCR with hot start conditions to minimize non-specific annealing of primers to templates and formation of primer dimers. Some of these buffers include ammonium ions (e.g. tetramethylammonium chloride) to destabilize the weak hydrogen bonds formed with non-specific priming. The commercially available multiplex PCR buffers may work well with a range of primers; however optimisation of the reaction components and cycling conditions is essential.

Commercially available buffers and manufacturers' recommendations for multiplex PCR show convincing amplifications for each of the targeted sequences. However, these conditions have been optimized with purified target nucleic sequences or plasmid clones. In our experience, optimal PCR conditions may be different with purified targets titrated in buffers as against those with various specimen types. It is helpful to determine optimal conditions using specimens (spiked with the specific agents) that are known to be negative (Kok et al., 2000).

\section{Real-time multiplex PCR}

The advantages of real-time PCR over conventional PCR also apply to real-time multiplex PCR. Fluorescent probes with different excitation wavelengths can be used to detect and estimate the relative amounts of the amplified products. FRET single-labelled hybridization probes have two advantages over Taqman-type probes. Firstly, the length of the hybridisation target for FRET probes is approximately twice that Taqman probes, thereby increasing detection specificity. Secondly, analysis of the melting-point of the FRET probe-target hybrid provides presumptive strain differentiation. The following examples illustrate the use of real-time multiplex PCR to detect and subtype cutaneous viruses (herpes simplex and varicella zoster viruses) and respiratory viruses (influenza A and B and respiratory syncytial viruses).

\section{Herpes simplex and varicella zoster virus detection and subtyping}

One of the characteristic features of herpes virus infection is the ability to cause latency and subsequent reactivation. Two of the more common clinical manifestations of herpes simplex virus infection are cold sores and genital lesions. There are two subtypes of HSV, viz. HSV 1 and HSV 2. Reactivation with HSV 1 virus is reported to occur at a lower frequency than HSV 2 virus, with the latter commonly infecting genital sites (Simmons, 2002; Whitley and Gnann, 1993; Whitley et al., 1998). Chicken pox or varicella is caused by varicella zoster virus (VZV), a member of the herpes viruses (Connelly et al., 1993; Wharton, 1996). Herpes zoster (shingles) is seen mainly in adult life and is caused by reactivation of VZV in the previously infected person (Hope-Simpson, 1965). Isolation of these viruses in cell cultures take more than four days to yield a result and detection by immunoassays is not as sensitive, compared to PCR.

A real-time multiplex PCR is used for the detection, amplification and simultaneous subtyping of HSV 1 and 2 and VZV viruses with FRET hybridisation probes (Burrows et al., 2002). The HSV primers amplify a $140 \mathrm{bp}$ region of the DNA polymerase gene with LC Red 640 fluorophor as the acceptor probe. The VZV primers amplify a 162 bp region of gene 29 with LC Red 705 fluorophor as the acceptor probe. The primers, FRET probes, PCR master mix reagents and extracted DNA from each specimen are mixed in one reaction tube. The presence of either HSV or VZV is detected in this multiplex PCR. HSV, if present, may be subtyped by melting temperature determination, with the FRET probe (LC 640) and HSV 2 target DNA hybrid melting at $72.5^{\circ} \mathrm{C}, \mathrm{HSV} 1$ at $58.2^{\circ} \mathrm{C}$ (Fig. 2a). The presence of VZV in the sample is confirmed with a melting temperature of $69.2^{\circ} \mathrm{C}$ with the specific FRET probe (LC705) (Fig. 2b). The limit of detection for these viruses is $\sim 20$ copies per reaction.

\section{Respiratory viruses}

Respiratory syncytial and influenza A and B viruses are the predominant respiratory viruses in countries with temperate climates. Infection rates are highest during the winter or wet season. Influenza A has caused four major pandemics during the past centuries viz. H1N1 in 1918 and 1977 and H3N2 in 1957 and 1968 (www. who.int). Influenza A viruses are differentiated by their haemagglutinin (HA) and neuraminidase (NA) surface glycoproteins, of which there are $16 \mathrm{HA}$ and 9 NA subtypes. The various combinations of the influenza A subtypes are predominantly found in aquatic birds, ducks and geese. 
A

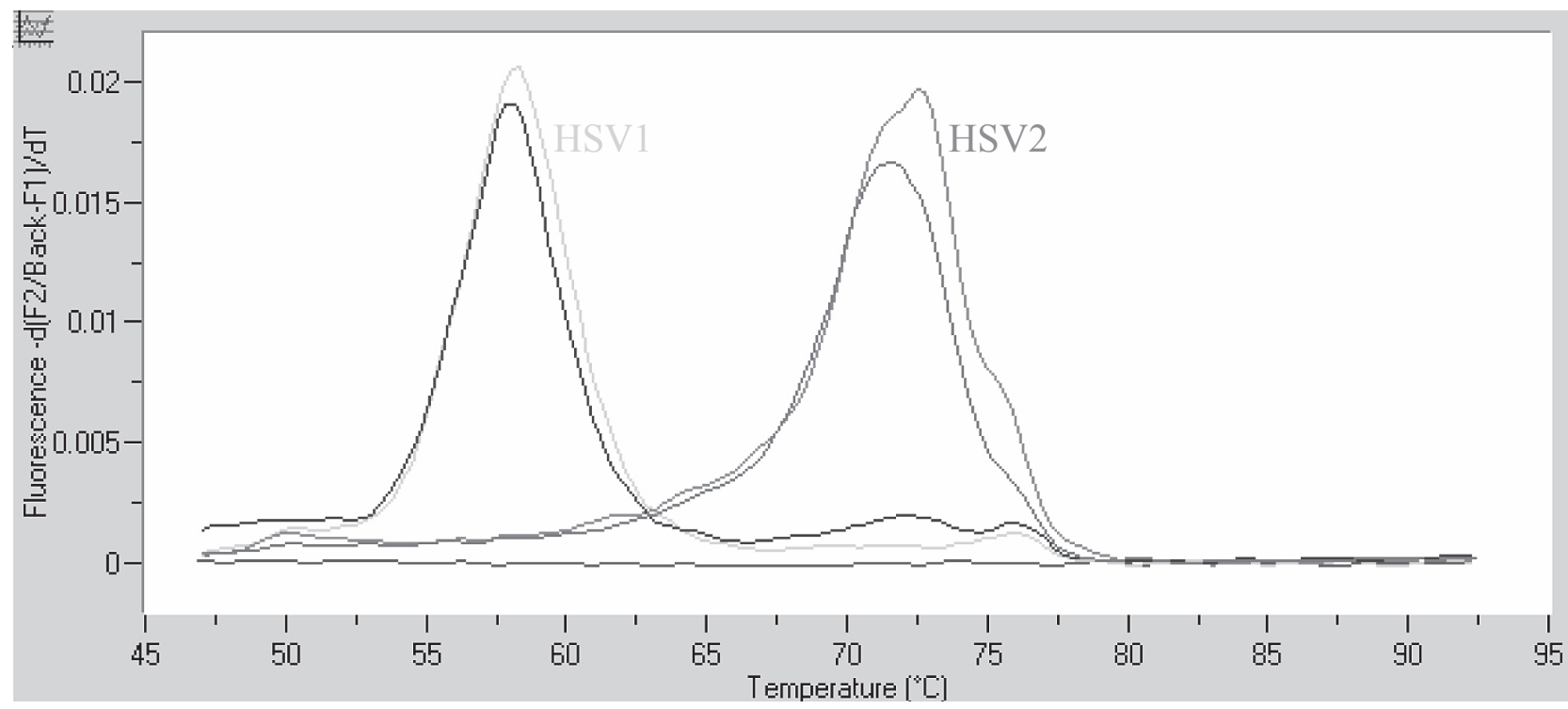

B

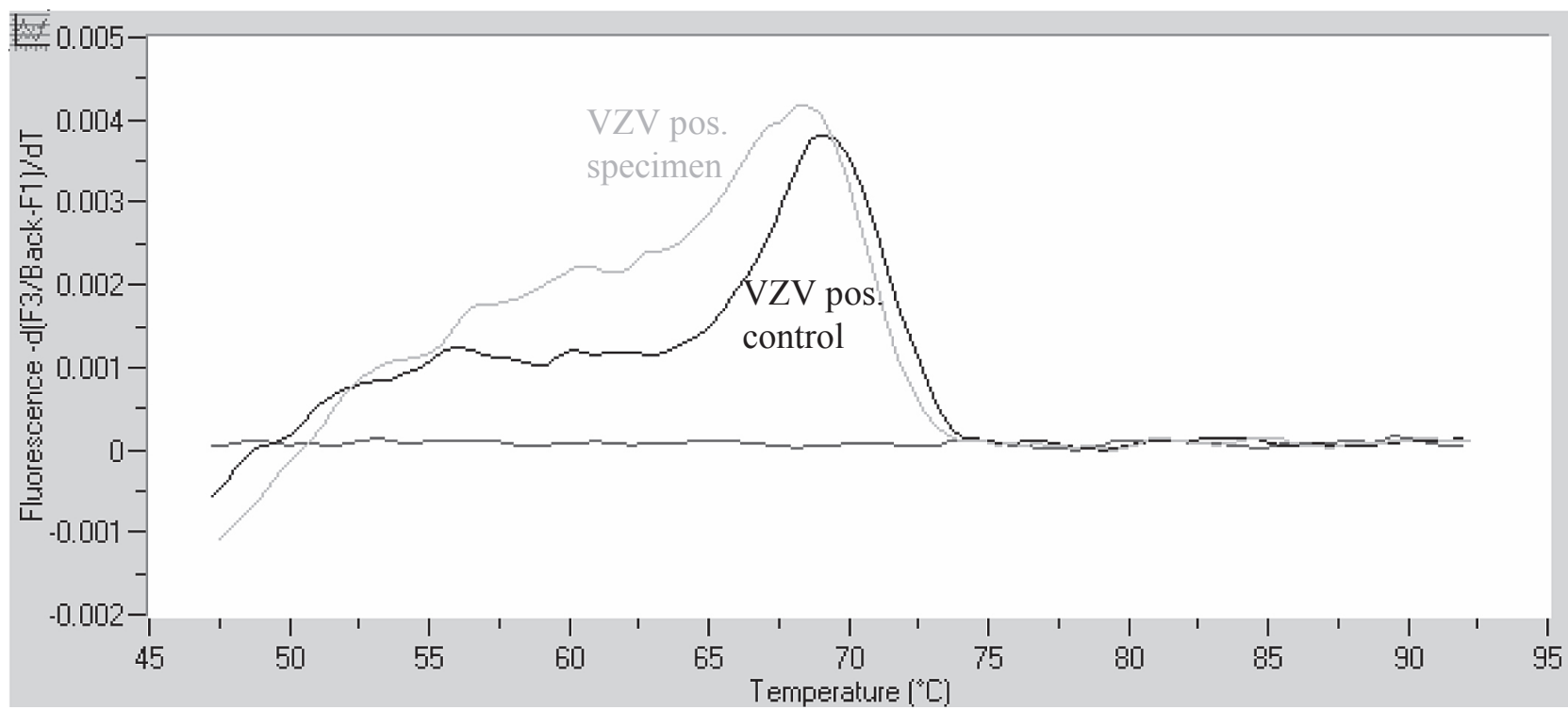

Fig. 2. Melting temperature graphs of specific FRET hybridisation probe and target HSV and VZV viruses in a multiplex real time PCR with HSV and VZV primers and FRET hybridisation probes. (a) Differentiation of HSV1 $\left(58.2^{\circ} \mathrm{C}\right)$ and $\mathrm{HSV} 2\left(72.5^{\circ} \mathrm{C}\right)$. The HSV FRET hybridisation probe $(\mathrm{LC} 640)$ is homologous to HSV2. (b) The VZV FRET probe is labelled with LC705 and has a melting temperature at $69.2^{\circ} \mathrm{C}$.

Influenza B infects humans only. The current circulating human strains of influenza A are HIN1 and H3N2. The trivalent, inactivated vaccine consists of these two strains and Influenza B.

Respiratory syncytial virus (RSV) is a major cause of paediatric bronchiolitis (>90\%) and pneumonia (>50\%) and is the most common cause of neonatal hospitalisation (Anonymous, 1978; Glezen et al., 1986). This virus is also a major cause of respiratory infections in adults (Falsey et al., 1995; Kok and Higgins, 1997) as well as the immunosuppressed and is responsible for $10 \%$ of hospitalisations. There are two subtypes of RSV, A and B. Both subtypes can co-circulate within the community during the same season. The isolation of RSV in cell cultures takes more than four days. Immunofluorescence and enzyme immunoassay tests have been widely used for rapid detection of RSV in respiratory exudate cells. However, these tests and isolation are not as sensitive as PCR.

We have developed an in-house multiplex real-time $\mathrm{PCR}$ that can detect and subtype these viruses (influenza A H1N1 and H3N2, influenza B, RSV-A and RSV-B) (Stone et al., 2004). The primers and FRET probes for these viruses and extracted RNA from each patient are included in the same reaction tube. The influenza A primers amplify the matrix gene with the use of FRET probes and LC705 that are designed to be homologous to H1N1. The influenza $\mathrm{B}$ primers amplify the haemagglutinin gene 
with the use of FRET probes and LC705. The melting temperatures of influenza A H1N1, H3N2 and Influenza B are $68.3^{\circ} \mathrm{C}, 63.5^{\circ} \mathrm{C}$ and $59.2^{\circ} \mathrm{C}$ respectively, which provide well separated differentiation values (Fig. 3a). The RSV primers amplify the phosphoprotein gene with the FRET probes and LC640 homologous to subtype A (melting temperature $63.8^{\circ} \mathrm{C}$ ). If RSV subtype $B$ is detected, its melting temperature will be at $53.8^{\circ} \mathrm{C}$ (Fig. 3b). The limit of detection for these viruses is $\sim 400$ copies per reaction.

\section{The use of sequence analysis}

Sequencing of amplicons has proven to be a very useful diagnostic tool. As previously stated, this has resulted from the combination of economical and rapid sequencing chemistries, computer-based phylogenetic analysis software and electronic interrogation of Internetaccessible gene sequence databases. Sequence analysis within diagnostic virology focuses in two main areas, (1) the phylogenetic analysis of strains to study the epidemiology of infectious outbreaks, and (2) the detection and monitoring of drug resistance-associated mutations associated with antiviral therapy.

\section{Sequence-based phylogenetic analysis}

Genotypic variation is akin to a '4 nucleotide base' digital signal. With 400 character states per 100 bases of sequence, sequence-based phylogenetic analysis facilitates substantial resolution between strains, far

A

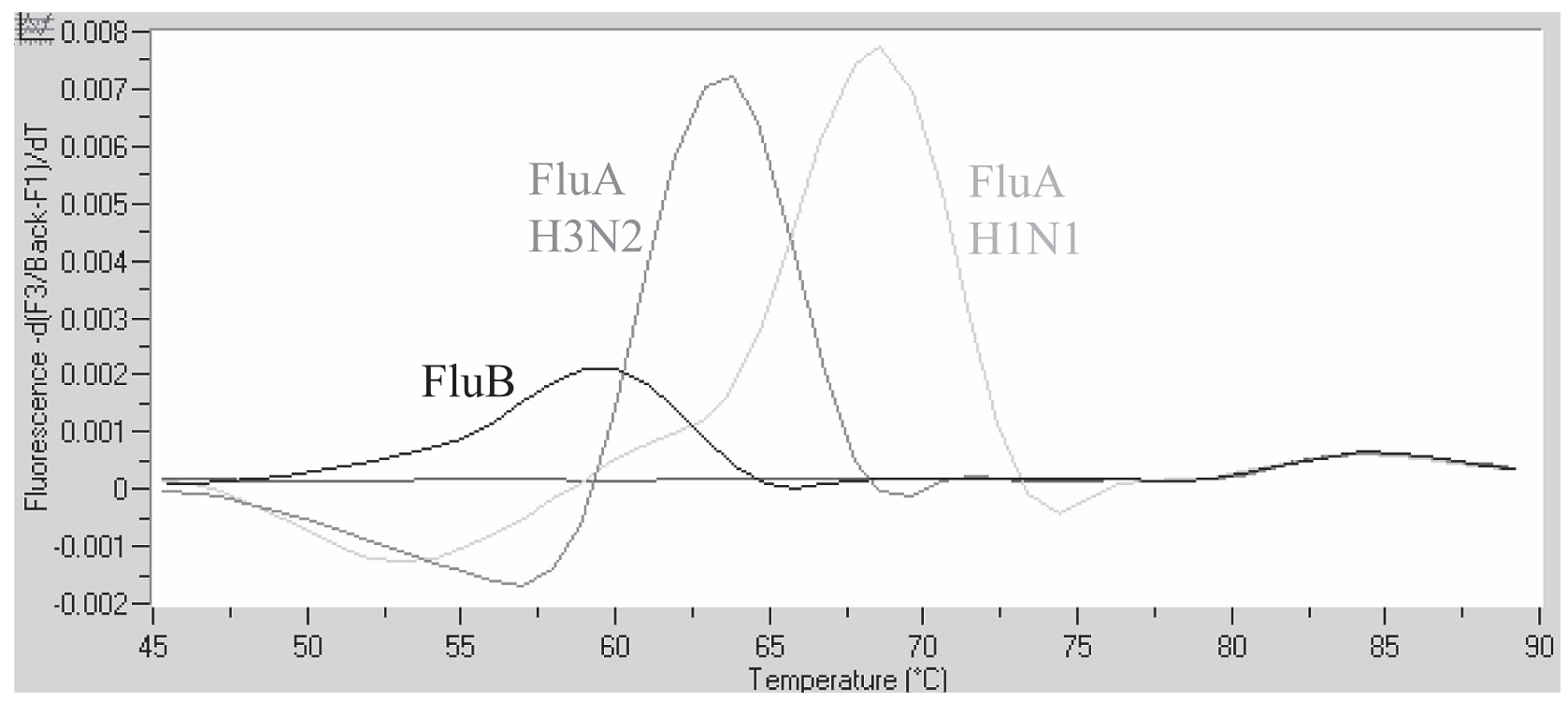

B

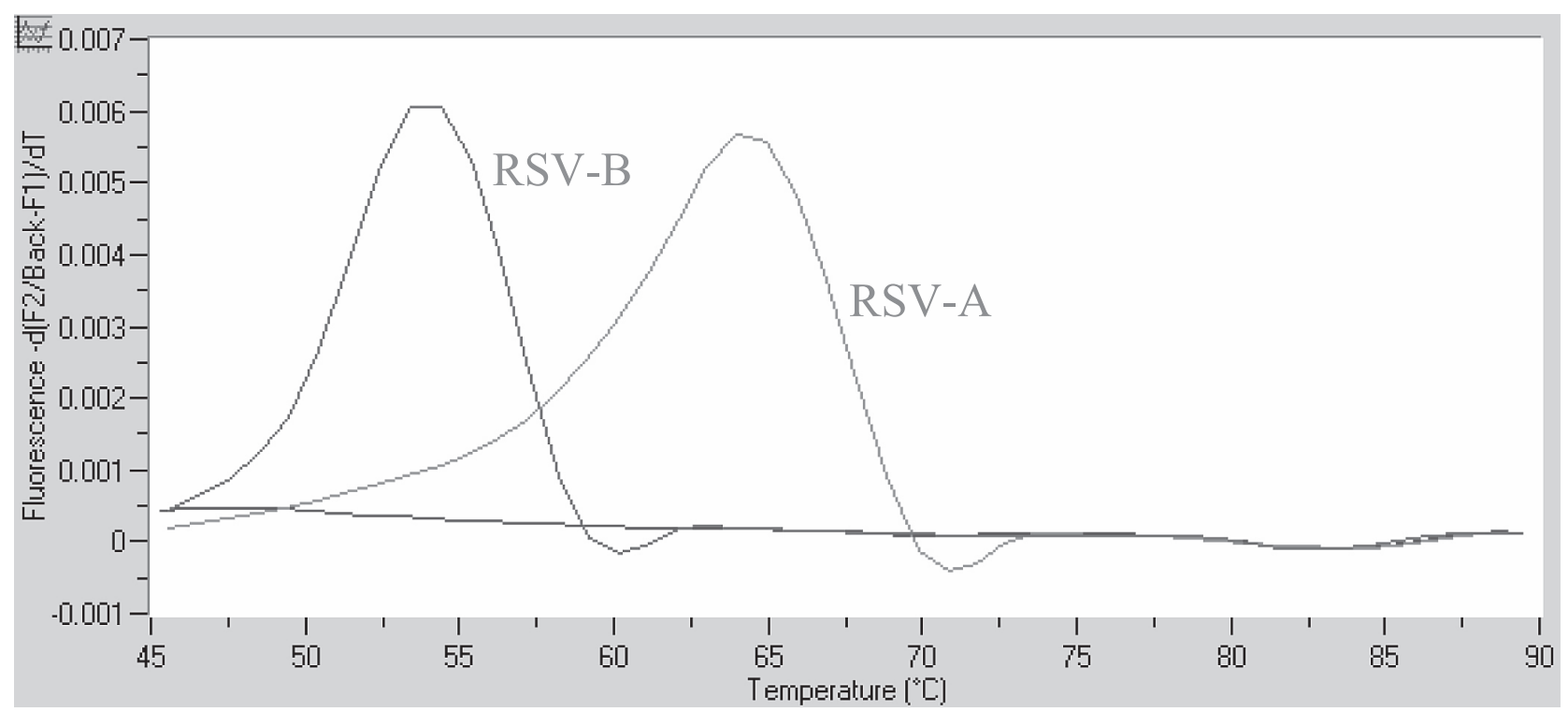

Fig. 3. Melting temperature graphs of specific hybridisation probe and target influenza $A$, influenza $B$ and RSV viruses in a multiplex real time PCR with the respective FRET hybridisation probes. (a) The influenza A FRET hybridisation probe (LC705) is homologous to influenza A H1N1 $\left(68.3^{\circ} \mathrm{C}\right)$ and $\mathrm{H} 3 \mathrm{~N} 2$ is differentiated by a melting temperature at $63.5^{\circ} \mathrm{C}$. (b) The influenza B FRET hybridisation probe (LC705) and target melts at $59.2^{\circ} \mathrm{C}$ (Figure $2 \mathrm{a}$ ). The RSV FRET probe (LC640) is homologous to RSV subtype A and melts at $63.8^{\circ} \mathrm{C}$. RSV subtype $\mathrm{B}$ has a lower melting temperature at $53.8^{\circ} \mathrm{C}$. 
in excess of any phenotypic marker/s, although in reality, functional constraint on mutation restricts the number of informative sites to approximately 30-50 per 100 bases, often to the redundant codon base sites in the protein-encoding regions normally targeted. The sequence analysis of amplicons obtained from positive samples allows for the very informative comparison of strain differences, to identify outbreaks, both for local community outbreaks affecting an isolated cluster of patients, and also to trace the global spread of important pandemic strains. To continue the example of the detection of noroviruses presented previously, while the conserved $A$ and $B$ regions within ORF-1 are very suitable for sensitive detection of genetically variable viruses, the more variable antigenic capsid-encoding regions within ORF-2 are far more phylogenetically informative (Kojima et al., 2002; Noel et al., 1997; Vinje et al., 2004). Such sequences also better reflect the immuno-selection to which the virus particles are subject during transmission in the community. Consequently, two regions within ORF-2 have been successfully targeted for subtyping of strains (designated regions $C$ and $D$ ), resulting in 8 and 17 subtypes of norovirus genotypes 1 and 2 respectively being recently proposed (Zheng et al., 2006). Such resolution is not possible when analysing sequence from regions $A$ and $B$ of ORF-1, and demonstrates the need to carefully consider which segment of a viral genome is to be targeted. The increased genetic variability of such sites can make successful amplification of product from these regions in all strains problematic, and highlights the often opposing issues of amplification sensitivity/broad reactivity and phylogenetic resolution which need to be balanced in designing a diagnostic amplification test. The use of sequence analysis software, such as Kodon (Applied Maths, Sint-Martens-Latem, Belgium), to correct, manage and compare sequences from an outbreak and with reference strains, is recommended.

\section{Antiviral therapy and drug resistance-associated mutations}

Highly potent antiviral therapies are available for treating a number of viral infections, such as HIV, HBV, HCV, influenza virus and herpes viruses including CMV, HSV and VZV. Antiviral therapies interfere with viral replication that is intimately associated with the host cell and therefore are also toxic to the host. They target viralencoded enzymes required for viral replication, such as protease inhibitors (PI), nucleoside and non-nucleoside reverse-transcriptase inhibitors (NRTI and NNRTI) and more recently fusion inhibitors (FI) for HIV, reversetranscriptase inhibitors for HBV and protein kinase (UL97) and DNA polymerase (UL54) inhibitors for CMV.

\section{Drug resistance and resistant mutants}

The virus's ability to develop resistance to antiviral drugs has become the focus of physicians since 1996 with the arrival of Highly Active Antiretroviral Therapy (HAART) for treating HIV (Mirken, 1997; Stephenson, 1997). Since then, drug-resistant strains in other viral infections such as chronic HBV and immuno-compromized patients infected with herpes viruses have also been reported with increasing frequency (Chou et al., 2003; Ono-Nita et al.,
1999; Springer et al., 2005; Tipples et al., 1996; Xiong et al., 2000). The development of drug resistance is caused by multiple factors; (a) the kinetics or dynamics of viral production and viral clearance, (b) error proneness of the viral reverse transcription, (c) structural flexibility of viral enzymes, (d) the potency of antiviral drug combinations, (e) the pharmaco-kinetic properties of the antiviral drug, (f) the mutations selected by target-specific drugs, (g) the patient's prior drug experience, and $(h)$ the patient's adherence to therapy (Richman, 2000).

\section{Viral fitness of resistant mutants}

It has been reported that drug-resistant mutants have reduced fitness (replication capacity) compared with drug-susceptible variants in vitro (Lucas, 2005; Melegari et al., 1998). Persistence of drug-resistant variants with reduced replication capacity may offer some clinical benefit (Buckheit, 2004; Hirsch et al., 2003; Springer et al., 2005). However, the benefits may be reduced by compensatory mutations in other regions that restore impairment of fitness. As a result, the risk of resistant mutants being transmitted to susceptible individuals is increased. Therefore, combination therapy to completely suppress ongoing replication is recommended to prevent the emergence of resistance mutations (Richman, 2000).

\section{Transmission of resistant mutants}

In 1998, Hecht and colleagues reported the first documented case of high-level resistance to protease inhibitors in a newly infected treatment-naive HIV patient (Hecht et al., 1998). Since this initial report, there have been many reports on the transmission of resistance mutations (Erice et al., 1993). It is believed that while HAART is improving both the length and quality of life in HIV patients, resistant strains arise when the patient compliance is poor. When these resistant strains are transmitted to susceptible individuals, choosing an effective treatment regimen for them can be difficult. If the resistance profile is unknown, sub-optimal first-line therapy will result (Tang and Pillay, 2004).

\section{Determination of drug resistance profiles}

The right treatment regimen will lead to a greater chance of long-term success and a reduced possibility of developing drug resistance. A suitable test is required to determine drug resistance profiles, both in treatmentnaive patients and for viral rebound in patients already on treatment, to establish if resistance has developed which requires a change in treatment (Mirken, 1997). Two types of resistance testing assays have since been developed; phenotypic and genotypic assays. Phenotypic assays test the actual ability of the infecting virus, or its relevant gene inserted into a recombinant virus, to replicate in cell culture in the presence of a drug or drugs. Genotypic tests, on the other hand, identify specific genetic mutations in the virus which correlate with phenotypic resistance (Hirsch et al., 2003; MacArthur, 2004). Multiple studies have shown that either genotypic antiretroviral resistance testing or phenotypic antiretroviral resistance testing provides useful information to help achieve a better short-term virological outcome in patients who are about to start their next antiretroviral regimen (Baxter et al., 2000; Cohen et 
al., 2002; Durant et al., 1999; Tural et al., 2002). While phenotyping and genotyping show excellent correlation $\left(R^{2}>0.8\right)$ for HIV (Hirsch et al., 2003), neither phenotyping nor genotyping can effectively detect all resistant strains in the case of herpes virus infection in immunocompromized patients. A combination of phenotypic and genotypic assays is recommended for the complete analysis of antiviral resistance in herpes virus infections (Andrei et al., 2001; Chou et al., 2003; Gilbert and Boivin, 2003; Scott et al., 2004). Phenotyping is cumbersome to perform, time-consuming and expensive, and therefore not readily available in general laboratories. Such issues restrict the practical worth of phenotyping to confirm the clinical outcome. Genotypic assays, on the other hand, are faster and less expensive, and as a consequence are now in much wider use (MacArthur, 2004). Currently, there are three types of genotyping assays available, Dideoxynucleotide Terminator Cycle Sequencing (DTCS), DNA Chips (High-density oligo-nucleotide arrays, e.g. Affimetrix) and Point Mutation Assays (e.g. InnoLipa). DTCS may be performed using assay kits (e.g. TRUGENETM HIV-1 Genotyping Kit, [Visible Genetics, Suwanee, GA], or ViroSeq ${ }^{\mathrm{TM}}$ HIV-1 Genotyping System $[\mathrm{ABI}])$ or in-house techniques (Gunthard et al., 1998) and is the most common genotyping method in use. It involves a PCR amplification (or RT-PCR for RNA viruses) of the target region in the viral gene, followed by cycle sequencing of the amplified gene using dye terminator chemistry and analysed by a DNA analyser (e.g. ABI 3700 DNA Analyser). The specific viral sequence is then edited using an editing program (e.g. Windows-based Kodon [Applied Maths] or Macintosh-based Sequence Navigator $[A B I])$. The interpretation of resistance profiles can be very complicated since, as mentioned earlier, patients are most likely to receive combination treatment. Although it is important to learn the resistance profile of individual drugs, consideration should also be given to drug-drug interactions. It is particularly important to choose a suitable combination treatment with non-overlapping toxicity profiles and complementary resistance profiles (Richman, 2000).

For HIV genotyping using in-house assays, interpretation of resistance profiles can easily be achieved by submitting the sequence from the patient to one of the readily available data bases e.g. Stanford HIV Drug Resistance Database (http://hivdb.stanford.edu) or Los Alamos National Laboratory - HIV Drug Resistance Database (resdb.lanl.gov/Resist_DB/default.htm) or commercially available interpretation programs. However, Sturmer and colleagues reported some inconsistencies in the interpretation between nine different resistance interpretation systems (Sturmer et al., 2003). Therefore, before selecting an interpretation system, it is essential to find out how the system is managed and, in particular, how often the system is updated and whether references for individual mutations are available (Johnson et al., 2005).

Unlike HIV, patients infected with HBV often only receive monotherapy. Resistance mutations usually develop within a few months of lamivudine monotherapy. Because of the overlapping reading frame of the hepatitis $B$ surface antigen, drug resistance mutations in the DNA polymerase also impact on hepatitis B surface antigen and its function. Therefore, both $\mathrm{Pol}$ and $\mathrm{S}$ reading frames must be analysed when interpreting resistance profiles (Bozdayi et al., 2004; Oon et al., 1999; Richman, 2000). Confusion can arise from inconsistent numbering of amino acids within the HBV polymerase, the result of amino acid insertions or deletions which occur frequently among the variable HBV genotypes. A more consistent consensus RT domain numbering system has recently been proposed which is independent of genotype variability, allowing a standardized analysis of amino acid changes (Stuyver et al., 2001).

\section{Recent developments and the future}

Several new antiretroviral agents are currently being developed, with some already in clinical trials. The functions of these agents are listed below:

- Inhibiting HIV Integrase protein

- Targeting the ejection of zinc ions from zinc finger proteins

- Inhibiting all steps of viral entry

- Interacting with Tat/Tar viral proteins

- Targeting other unexploited cellular (Tsg101, APOBEC3G) or viral (Vif, Rev or Rnase H) proteins (Barbaro et al., 2005).

In recent years, the application of gene therapy in viral infections has become a major research focus in an attempt to search for alternatives to the current anti-viral therapy. The use of ribozyme and small antisense RNA to inhibit HIV replication has shown some promise in vitro. Such therapies may replace the current treatments and the need to monitor drug resistance profiles. (PuertaFernandez et al., 2005; Shankar et al., 2005; Wolkowicz and Nolan, 2005).

\section{Conclusions}

As molecular methods have evolved and facilitated a major contribution to the diagnosis of human viral disease, there has been an increasing awareness for the need for quality assurance in order to produce clinically relevant results. In addition, the targeted nature of PCR brings with it some inherent limitations that are difficult to control, particularly in virology, where the heterogeneous nature of the viral genome may lead to difficulties in assay design and performance. Nevertheless, an awareness of these issues will ultimately result in a better understanding of this new technology, and enable the full exploration of the potential of these modern diagnostic tools.

\section{References}

Abu Al-Soud, W., and Radstrom, P. (2000). Effects of amplification facilitators on diagnostic PCR in the presence of blood, feces, and meat. J. Clin. Microbiol 38, 4463-4470.

Al-Soud, W.A., Ouis, I.S., Li, D.Q., Ljungh, S., and Wadstrom, T. (2005). Characterization of the PCR inhibitory effect of bile to optimize real-time PCR detection of Helicobacter species. FEMS Immunol. Med. Microbiol. 44, 177-182. 
Al-Soud, W.A., and Radstrom, P. (2001). Purification and characterization of PCR-inhibitory components in blood cells. J. Clin. Microbiol. 39, 485-493.

Ando, T., Noel, J.S., and Fankhauser, R.L. (2000). Genetic classification of "Norwalk-like viruses". J. Infect. Dis. 181, S336-348.

Andrei, G., Fiten, P., De Clercq, E., Snoeck, R., and Opdenakker, G. (2001). Evaluating phenotype and genotype of drug-resistant strains in herpesviruses. Mol. Biotechnol. 18, 155-167.

Anonymous. (1978). Respiratory syncytial virus infection: admissions to hospital in industrial, urban, and rural areas. Report to the Medical Research Council Subcommittee on Respiratory Syncytial Virus Vaccines. British Med. J. 2, 796-798.

Barbaro, G., Scozzafava, A., Mastrolorenzo, A., and Supuran, C.T. (2005). Highly active antiretroviral therapy: current state of the art, new agents and their pharmacological interactions useful for improving therapeutic outcome. Curr. Pharm. Des. 11, 18051843.

Baxter, J.D., Mayers, D.L., Wentworth, D.N., Neaton, J.D., Hoover, M.L., Winters, M.A., Mannheimer, S.B., Thompson, M.A., Abrams, D.I., Brizz, B.J., et al. (2000). A randomized study of antiretroviral management based on plasma genotypic antiretroviral resistance testing in patients failing therapy. CPCRA 046 Study Team for the Terry Beirn Community Programs for Clinical Research on AIDS. Aids 14, F83-93.

Berger, A., Doerr, H.W., and Weber, B. (1998). Human immunodeficiency virus and hepatitis $B$ virus infection in pregnancy: diagnostic potential of viral genome detection. Intervirology 41, 201-207.

Bernard, P.S., Lay, M.J., and Wittwer, C.T. (1998). Integrated amplification and detection of the C677T point mutation in the methylenetetrahydrofolate reductase gene by fluorescence resonance energy transfer and probe melting curves. Anal. Biochem. 255, 101-107.

Boeckh, M., and Boivin, G. (1998). Quantitation of cytomegalovirus: methodologic aspects and clinical applications. Clin. Microbiol. Rev. 11, 533-554.

Bozdayi, A.M., Eyigun, C.P., Turkyilmaz, A.R., Avci, I.Y., Pahsa, A., and Yurdaydin, C. (2004). A novel pattern (sW195a) in surface gene of HBV DNA due to YSDD (L180M plus M204S) mutation selected during lamivudine therapy and successful treatment with adefovir dipivoxil. J Clin. Virol. 31, 76-77.

Buckheit, R.W., Jr. (2004). Understanding HIV resistance, fitness, replication capacity and compensation: targeting viral fitness as a therapeutic strategy. Expert Opin. Investig. Drugs 13, 933-958.

Burrows, J., Nitsche, A., Bayly, B., Walker, E., Higgins, G., and Kok, T. (2002). Detection and subtyping of Herpes simplex virus in clinical samples by LightCycler PCR, enzyme immunoassay and cell culture. B.M.C. Microbiol. 2, 12.

Chamberlain, J.S., Gibbs, R.A., Ranier, J.E., Nguyen, P.N., and Caskey, C.T. (1988). Deletion screening of the Duchenne muscular dystrophy locus via multiplex DNA amplification. Nucleic Acids Res. 16, 11141-11156.

Chou, S., Lurain, N.S., Thompson, K.D., Miner, R.C., and Drew, W.L. (2003). Viral DNA polymerase mutations associated with drug resistance in human cytomegalovirus. J. Infect. Dis. 188, 32-39.

Cohen, C.J., Hunt, S., Sension, M., Farthing, C., Conant, M., Jacobson, S., Nadler, J., Verbiest, W., Hertogs, K., Ames, M., et al. (2002). A randomized trial assessing the impact of phenotypic resistance testing on antiretroviral therapy. Aids 16, 579-588.

Connelly, B.L., Stanberry, L.R., and Bernstein, D.I. (1993). Detection of varicella-zoster virus DNA in nasopharyngeal secretions of immune household contacts of varicella. J. Infect. Dis. 168, 1253-1255.

Daar, E.S., Moudgil, T., Meyer, R.D., and Ho, D.D. (1991). Transient high levels of viremia in patients with primary human immunodeficiency virus type 1 infection. N. Engl. J. Med. 324, 961-964.

Durant, J., Clevenbergh, P., Halfon, P., Delgiudice, P., Porsin, S., Simonet, P., Montagne, N., Boucher, C.A., Schapiro, J.M., and Dellamonica, P. (1999). Drugresistance genotyping in HIV-1 therapy: the VIRADAPT randomised controlled trial. Lancet 353, 2195-2199.

Erice, A., Mayers, D.L., Strike, D.G., Sannerud, K.J., McCutchan, F.E., Henry, K., and Balfour, H.H., Jr. (1993). Brief report: primary infection with zidovudineresistant human immunodeficiency virus type $1 . \mathrm{N}$. Engl. J. Med. 328, 1163-1165.

Espy, M.J., Uhl, J.R., Mitchell, P.S., Thorvilson, J.N., Svien, K.A., Wold, A.D., and Smith, T.F. (2000). Diagnosis of herpes simplex virus infections in the clinical laboratory by LightCycler PCR. J. Clin. Microbiol. 38, 795-799.

Falsey, A.R., Cunningham, C.K., Barker, W.H., Kouides, R.W., Yuen, J.B., Menegus, M., Weiner, L.B., Bonville, C.A., and Betts, R.F. (1995). Respiratory syncytial virus and influenza A infections in the hospitalized elderly. J. Infect. Dis. 172, 389-394.

Fankhauser, R.L., Monroe, S.S., Noel, J.S., Humphrey, C.D., Bresee, J.S., Parashar, U.D., Ando, T., and Glass, R.I. (2002). Epidemiologic and molecular trends of "Norwalk-like viruses" associated with outbreaks of gastroenteritis in the United States. J. Infect. Dis. 186, 1-7.

Gilbert, C., and Boivin, G. (2003). Discordant phenotypes and genotypes of cytomegalovirus (CMV) in patients with AIDS and relapsing CMV retinitis. Aids 17, 337341.

Glass, R.I., Noel, J., Ando, T., Fankhauser, R., Belliot, G., Mounts, A., Parashar, U.D., Bresee, J.S., and Monroe, S.S. (2000). The epidemiology of enteric caliciviruses from humans: a reassessment using new diagnostics. J. Infect. Dis. 181, S254-261.

Glezen, W.P., Taber, L.H., Frank, A.L., and Kasel, J.A. (1986). Risk of primary infection and reinfection with respiratory syncytial virus. Am. J. Dis. Child 140, 543546.

Gunthard, H.F., Wong, J.K., Ignacio, C.C., Havlir, D.V., and Richman, D.D. (1998). Comparative performance of high-density oligonucleotide sequencing and dideoxynucleotide sequencing of HIV type 1 pol from clinical samples. AIDS Res. Hum. Retroviruses 14, 869-876.

Hecht, F.M., Grant, R.M., Petropoulos, C.J., Dillon, B., Chesney, M.A., Tian, H., Hellmann, N.S., Bandrapalli, N.I., Digilio, L., Branson, B., and Kahn, J.O. (1998). 
Sexual transmission of an HIV-1 variant resistant to multiple reverse-transcriptase and protease inhibitors. N. Engl. J. Med. 339, 307-311.

Heid, C.A., Stevens, J., Livak, K.J., and Williams, P.M. (1996). Real time quantitative PCR. Genome Res. 6, 986-994.

Hirsch, M.S., Brun-Vezinet, F., Clotet, B., Conway, B., Kuritzkes, D.R., D'Aquila, R.T., Demeter, L.M., Hammer, S.M., Johnson, V.A., Loveday, C., et al. (2003). Antiretroviral drug resistance testing in adults infected with human immunodeficiency virus type 1: 2003 recommendations of an International AIDS Society-USA Panel. Clin. Infect. Dis. 37, 113-128.

Hiyoshi, M., and Hosoi, S. (1994). Assay of DNA denaturation by polymerase chain reaction-driven fluorescent label incorporation and fluorescence resonance energy transfer. Anal. Biochem. 221, 306311.

Holland, P.M., Abramson, R.D., Watson, R., and Gelfand, D.H. (1991). Detection of specific polymerase chain reaction product by utilizing the 5'----3' exonuclease activity of Thermus aquaticus DNA polymerase. Proc. Natl. Acad. Sci. USA. 88, 7276-7280.

Hope-Simpson, R.E. (1965). The Nature of Herpes Zoster: A Long-Term Study and a New Hypothesis. Proc. R. Soc. Med. 58, 9-20.

Jiang, X., Huang, P.W., Zhong, W.M., Farkas, T., Cubitt, D.W., and Matson, D.O. (1999). Design and evaluation of a primer pair that detects both Norwalk- and Sapporolike caliciviruses by RT-PCR. J. Virol. Methods 83, 145154.

Johnson, V.A., Brun-Vezinet, F., Clotet, B., Conway, B., Kuritzkes, D.R., Pillay, D., Schapiro, J., Telenti, A., and Richman, D. (2005). Update of the Drug Resistance Mutations in HIV-1: 2005. Top. HIV Med. 13, 51-57.

Kageyama, T., Kojima, S., Shinohara, M., Uchida, K., Fukushi, S., Hoshino, F.B., Takeda, N., and Katayama, K. (2003). Broadly reactive and highly sensitive assay for Norwalk-like viruses based on real-time quantitative reverse transcription-PCR. J. Clin. Microbiol. 41, 15481557.

Kamal, S.M., El Tawil, A.A., Nakano, T., He, Q., Rasenack, J., Hakam, S.A., Saleh, W.A., Ismail, A., Aziz, A.A., and Madwar, M.A. (2005). Peginterferon $\alpha-2 b$ and ribavirin therapy in chronic hepatitis $C$ genotype 4: impact of treatment duration and viral kinetics on sustained virological response. Gut 54, 858-866.

Kojima, S., Kageyama, T., Fukushi, S., Hoshino, F.B., Shinohara, M., Uchida, K., Natori, K., Takeda, N., and Katayama, K. (2002). Genogroup-specific PCR primers for detection of Norwalk-like viruses. J. Virol. Methods 100, 107-114.

Kok, T., and Higgins, G. (1997). Prevalence of respiratory viruses and Mycoplasma pneumoniae in sputum samples from unselected adult patients. Pathology 29, 300-302.

Kok, T., Wati, S., Bayly, B., Devonshire-Gill, D., and Higgins, G. 2000. Comparison of six nucleic acid extraction methods for detection of viral DNA or RNA sequences in four different non-serum specimen types. J. Clin. Virol. 16, 59-63.
Kowala-Piaskowska, A., Figlerowicz, M., Mozer-Lisewska, I., Mazur-Melewska, K., Pawelek, T., and Sluzewski, W. (2004). Vertical transmission of hepatitis C virus infection. Hepatol. Res. 30, 137-140.

Kumar, R., Vandegraaff, N., Mundy, L., Burrell, C.J., and Li, P. (2002). Evaluation of PCR-based methods for the quantitation of integrated HIV-1 DNA. J. Virol. Methods. 105, 233-246.

Kutyavin, I.V., Afonina, I.A., Mills, A., Gorn, V.V., Lukhtanov, E.A., Belousov, E.S., Singer, M.J., Walburger, D.K., Lokhov, S.G. Gall, A.A., Dempcy, R., Reed, M.W., Meyer, R.B. and Hedgpeth, J. (2000) 3'-Minor groove binder-DNA probes increase sequence specificity at PCR extension temperatures. Nucleic Acids Res. 28, 655-661.

Lay, M.J., and Wittwer, C.T. (1997). Real-time fluorescence genotyping of factor $\mathrm{V}$ Leiden during rapid-cycle PCR. Clin. Chem. 43, 2262-2267.

Lee, L.G., Connell, C.R., and Bloch, W. (1993). Allelic discrimination by nick-translation PCR with fluorogenic probes. Nucleic Acids Res. 21, 3761-3766.

Livak, K.J., Flood, S.J., Marmaro, J., Giusti, W., and Deetz, K. (1995). Oligonucleotides with fluorescent dyes at opposite ends provide a quenched probe system useful for detecting PCR product and nucleic acid hybridization. PCR Methods Appl. 4, 357-362.

Lucas, G.M. (2005). Antiretroviral adherence, drug resistance, viral fitness and HIV disease progression: a tangled web is woven. J. Antimicrob. Chemother. 55, 413-416.

MacArthur, R.D. (2004). An updated guide to genotype interpretation. AIDS Read 14, 256-266.

Melegari, M., Scaglioni, P.P., and Wands, J.R. (1998). Hepatitis B virus mutants associated with 3TC and famciclovir administration are replication defective. Hepatology 27, 628-633.

Mellors, J.W., Rinaldo, C.R., Jr., Gupta, P., White, R.M., Todd, J.A., and Kingsley, L.A. (1996). Prognosis in HIV1 infection predicted by the quantity of virus in plasma. Science 272, 1167-1170.

Mhlanga, M.M., and Malmberg, L. (2001). Using molecular beacons to detect single-nucleotide polymorphisms with real-time PCR. Methods 25, 463-471.

Mirken, B. (1997). HIV resistance testing: more questions than answers. AIDS Treat News, 3-5.

Noel, J.S., Ando, T., Leite, J.P., Green, K.Y., Dingle, K.E., Estes, M.K., Seto, Y., Monroe, S.S., and Glass, R.I. (1997). Correlation of patient immune responses with genetically characterized small round-structured viruses involved in outbreaks of nonbacterial acute gastroenteritis in the United States, 1990 to 1995. J. Med. Virol. 53, 372-383.

Monis, P.T., Giglio, S., and Saint, C.P. 2005. Comparison of SYTO9 and SYBR Green I for real-time polymerase chain reaction and investigation of the effect of dye concentration on amplification and DNA melting curve analysis. Anal. Biochem. 340, 24-34.

O'Doherty, U., Swiggard, W.J., Jeyakumar, D., McGain, D., and Malim, M.H. (2002). A sensitive, quantitative assay for human immunodeficiency virus type 1 integration. J. Virol. 76, 10942-10950. 
Olmos, A., Cambra, M., Esteban, O., Gorris, M.T., and Terrada, E. (1999). New device and method for capture, reverse transcription and nested PCR in a single closedtube. Nucleic Acids Res. 27, 1564-1565.

Ono-Nita, S.K., Kato, N., Shiratori, Y., Masaki, T., Lan, K.H., Carrilho, F.J., and Omata, M. (1999). YMDD motif in hepatitis $B$ virus DNA polymerase influences on replication and lamivudine resistance: A study by in vitro full-length viral DNA transfection. Hepatology 29, 939-945.

Oon, C.J., Chen, W.N., Lim, N., Koh, S., Lim, G.K., Leong, A.L., and Tan, G.S. (1999). Hepatitis B virus variants with lamivudine-related mutations in the DNA polymerase and the 'a' epitope of the surface antigen are sensitive to ganciclovir. Antiviral Res. 41, 113-118.

Puerta-Fernandez, E., Jesus, A.B., Romero-Lopez, C., Tapia, N., Martinez, M.A., and Berzal-Herranz, A. (2005). Inhibition of HIV-1 replication by RNA targeted against the LTR region. Aids 19, 863-870.

Ratcliff, R.M., Doherty, J.C., and Higgins, G.D. (2002). Sensitive detection of RNA viruses associated with gastroenteritis by a hanging-drop single-tube nested reverse transcription-PCR method. J. Clin. Microbiol. 40, 4091-4099.

Richman, D.D. (2000). The impact of drug resistance on the effectiveness of chemotherapy for chronic hepatitis B. Hepatology 32, 866-867.

Saha, B.K., Tian, B., and Bucy, R.P. (2001). Quantitation of HIV-1 by real-time PCR with a unique fluorogenic probe. J. Virol. Methods 93, 33-42.

Schneeberger, C., Speiser, P., Kury, F., and Zeillinger, R. (1995). Quantitative detection of reverse transcriptasePCR products by means of a novel and sensitive DNA stain. PCR Methods Appl. 4, 234-238.

Scott, G.M., Isaacs, M.A., Zeng, F., Kesson, A.M., and Rawlinson, W.D. (2004). Cytomegalovirus antiviral resistance associated with treatment induced UL97 (protein kinase) and UL54 (DNA polymerase) mutations. J. Med. Virol. 74, 85-93.

Shankar, P., Manjunath, N., and Lieberman, J. (2005). The prospect of silencing disease using RNA interference. Jama 293, 1367-1373.

Simmons, A. (2002). Clinical manifestations and treatment considerations of herpes simplex virus infection. J. Infect. Dis. 186 Suppl 1, S71-77.

Springer, K.L., Chou, S., Li, S., Giller, R.H., Quinones, R., Shira, J.E., and Weinberg, A. (2005). How evolution of mutations conferring drug resistance affects viral dynamics and clinical outcomes of cytomegalovirusinfected hematopoietic cell transplant recipients. J. Clin. Microbiol. 43, 208-213.

Stephenson, J. (1997). The art of 'HAART': researchers probe the potential and limits of aggressive HIV treatments. Jama 277, 614-616.

Stone, B., Burrows, J., Schepetiuk, S., Higgins, G., Hampson, A., Shaw, R., and Kok, T. (2004). Rapid detection and simultaneous subtype differentiation of influenza A viruses by real time PCR. J. Virol. Methods 117, 103-112.

Sturmer, M., Doerr, H.W., Staszewski, S., and Preiser, W. (2003). Comparison of nine resistance interpretation systems for HIV-1 genotyping. Antivir. Ther. 8, 239244.

Stuyver, L.J., Locarnini, S.A., Lok, A., Richman, D.D., Carman, W.F., Dienstag, J.L., and Schinazi, R.F. (2001). Nomenclature for antiviral-resistant human hepatitis B virus mutations in the polymerase region. Hepatology 33, 751-757.

Svanvik, N., Stahlberg, A., Sehlstedt, U., Sjoback, R., and Kubista, M. (2000). Detection of PCR products in real time using light-up probes. Anal. Biochem. 287, 179182.

Tang, J.W., and Pillay, D. (2004). Transmission of HIV-1 drug resistance. J Clin Virol 30, 1-10.

Tipples, G.A., Ma, M.M., Fischer, K.P., Bain, V.G., Kneteman, N.M., and Tyrrell, D.L. (1996). Mutation in HBV RNA-dependent DNA polymerase confers resistance to lamivudine in vivo. Hepatology 24, 714 717.

Trujillo, A.A., McCaustland, K.A., Zheng, D.-P., Hadley, L.A., Vaughn, G., Adams, S.M., Ando, T., Glass, R.I., and Monroe, S.S. (2006). Use of TaqMan real-time reverse transcription-PCR for rapid detection, quantification, and typing of norovirus. J. Clin. Microbiol. 44, 14051412.

Tural, C., Ruiz, L., Holtzer, C., Schapiro, J., Viciana, P., Gonzalez, J., Domingo, P., Boucher, C., Rey-Joly, C., and Clotet, B. (2002). Clinical utility of HIV-1 genotyping and expert advice: the Havana trial. Aids 16, 209-218.

Vinje, J., Hamidjaja, R.A., and Sobsey, M.D. (2004). Development and application of a capsid VP1 (region D) based reverse transcription PCR assay for genotyping of genogroup I and II noroviruses. J. Virol. Methods 16, 109-117.

Weusten, J.J., Carpay, W.M., Oosterlaken, T.A., van Zuijlen, M.C., and van de Wiel, P.A. (2002). Principles of quantitation of viral loads using nucleic acid sequencebased amplification in combination with homogeneous detection using molecular beacons. Nucleic Acids Res. 30, e26.

Wharton, M. (1996). The epidemiology of varicella-zoster virus infections. Infect. Dis. Clin. North Am. 10, 571581.

Whiley, D.M., Buda, P.J., Bayliss, J., Cover, L., Bates, J., and Sloots, T.P. (2004a). A new confirmatory Neisseria gonorrhoeae real-time $\mathrm{PCR}$ assay targeting the porA pseudogene. Eur J Clin. Microbiol. Infect. Dis. 23, 705710.

Whiley DM, Sloots TP. 2005. A 5'-nuclease real-time RT-PCR assay for the detection of a broad range of influenza A subtypes, including H5N1. Diagn.Microbiol. Infect. Dis. 53(4):335-337.

Whiley, D.M., Mackay, I.M., and Sloots, T.P. (2001). Detection and differentiation of human polyomaviruses JC and BK by LightCycler PCR. J. Clin. Microbiol. 39, 4357-4361.

Whiley, D.M., Mackay, I.M., Syrmis, M.W., Witt, M.J., and Sloots, T.P. (2004b). Detection and differentiation of herpes simplex virus types 1 and 2 by a duplex LightCycler PCR that incorporates an internal control $\mathrm{PCR}$ reaction. J. Clin. Virol. 30, 32-38.

Whiley, D.M., and Sloots, T.P. (2005a). Melting curve analysis using hybridisation probes: limitations in 
microbial molecular diagnostics. Pathology 37, 254265.

Whiley, D.M., and Sloots, T.P. (2005b). Sequence variation in primer targets affects the accuracy of viral quantitative PCR. J. Clin. Virol. 34, 104-107.

Whiley, D.M., Syrmis, M.W., Mackay, I.M., and Sloots, T.P. (2002). Detection of human respiratory syncytial virus in respiratory samples by LightCycler reverse transcriptase PCR. J Clin. Microbiol. 40, 4418-4422.

Whitley, R.J., and Gnann, J.W. (1993). The epidemiology and clinical manifestations of herpes simplex virus infections. In: The human herpesviruses, B. Roizman, R.J. Whitley, and C. Lopez, eds. (New York, Raven).

Whitley, R.J., Kimberlin, D.W., and Roizman, B. (1998). Herpes simplex viruses. Clin. Infect. Dis. 26, 541-553.

Wittwer, C.T., Ririe, K.M., Andrew, R.V., David, D.A., Gundry, R.A., and Balis, U.J. (1997). The LightCycler: a microvolume multisample fluorimeter with rapid temperature control. Biotechniques 22, 176-181.

Wolff, C., Hornschemeyer, D., Wolff, D., and Kleesiek, K. (1995). Single-tube nested PCR with room-temperaturestable reagents. PCR Methods Appl. 4, 376-379.

Wolkowicz, R., and Nolan, G.P. (2005). Gene therapy progress and prospects: novel gene therapy approaches for AIDS. Gene Ther. 12, 467-476.

Xiong, X., Yang, H., Westland, C.E., Zou, R., and Gibbs, C.S. (2000). In vitro evaluation of hepatitis B virus polymerase mutations associated with famciclovir resistance. Hepatology 31, 219-224.

Zheng, D.-P., Ando, T., Frankhauser, R.L., Beard, R.S., Glass, R.I., and Monroe, S.S. (2006). Norovirus classification and proposed strain nomenclature. Virology 346, 312-323. 


\section{Further Reading}

Caister Academic Press is a leading academic publisher of advanced texts in microbiology, molecular biology and medical research. Full details of all our publications at caister.com

- MALDI-TOF Mass Spectrometry in Microbiology Edited by: M Kostrzewa, S Schubert (2016) www.caister.com/malditof

- Aspergillus and Penicillium in the Post-genomic Era Edited by: RP Vries, IB Gelber, MR Andersen (2016) www.caister.com/aspergillus2

- The Bacteriocins: Current Knowledge and Future Prospects Edited by: RL Dorit, SM Roy, MA Riley (2016)

www.caister.com/bacteriocins

- Omics in Plant Disease Resistance Edited by: V Bhadauria (2016) www.caister.com/opd

- Acidophiles: Life in Extremely Acidic Environments Edited by: R Quatrini, DB Johnson (2016) www.caister.com/acidophiles

- Climate Change and Microbial Ecology: Current Research and Future Trend

Edited by: J Marxsen (2016)

www.caister.com/climate

- Biofilms in Bioremediation: Current Research and Emerging Technologies

Edited by: G Lear (2016)

www.caister.com/biorem

- Microalgae: Current Research and Applications Edited by: MN Tsaloglou (2016) www.caister.com/microalgae

- Gas Plasma Sterilization in Microbiology: Theory, Applications, Pitfalls and New Perspectives Edited by: H Shintani, A Sakudo (2016) www.caister.com/gasplasma

- Virus Evolution: Current Research and Future Directions Edited by: SC Weaver, M Denison, M Roossinck, et al. (2016) www.caister.com/virusevol

- Arboviruses: Molecular Biology, Evolution and Control Edited by: N Vasilakis, DJ Gubler (2016) www.caister.com/arbo

- Shigella: Molecular and Cellular Biology Edited by: WD Picking, WL Picking (2016) www.caister.com/shigella

-Aquatic Biofilms: Ecology, Water Quality and Wastewater Treatment

Edited by: AM Romaní, H Guasch, MD Balaguer (2016)

www.caister.com/aquaticbiofilms

- Alphaviruses: Current Biology

Edited by: S Mahalingam, L Herrero, B Herring (2016)

www.caister.com/alpha

- Thermophilic Microorganisms

Edited by: F Li (2015)

www.caister.com/thermophile
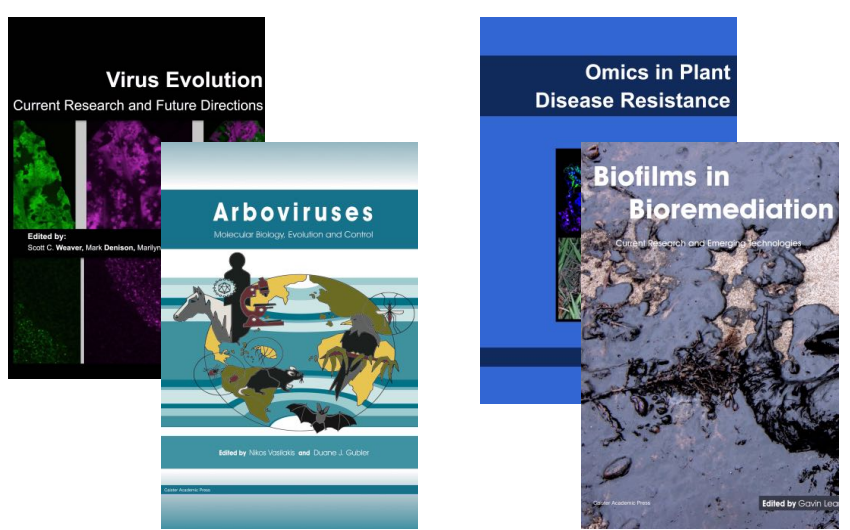
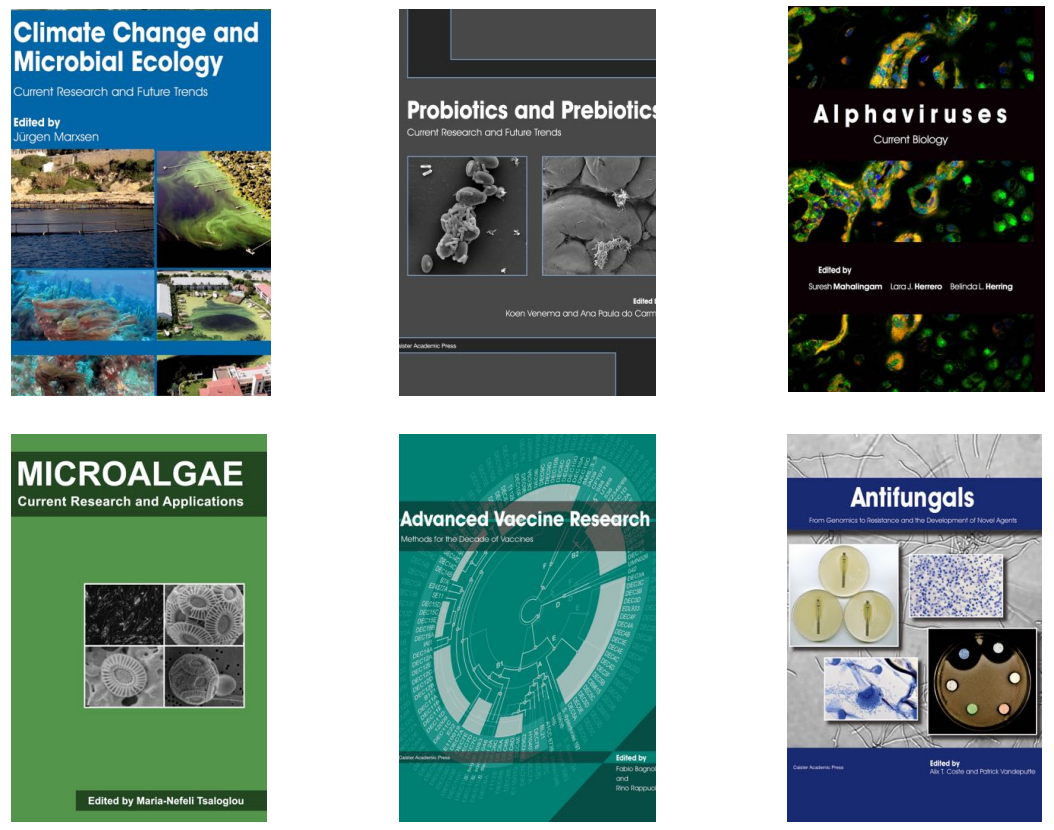

- Flow Cytometry in Microbiology: Technology and Applications Edited by: MG Wilkinson (2015) www.caister.com/flow

- Probiotics and Prebiotics: Current Research and Future Trends Edited by: K Venema, AP Carmo (2015) www.caister.com/probiotics

- Epigenetics: Current Research and Emerging Trends Edited by: BP Chadwick (2015) www.caister.com/epigenetics2015

- Corynebacterium glutamicum: From Systems Biology to Biotechnological Applications

Edited by: A Burkovski (2015)

www.caister.com/cory2

- Advanced Vaccine Research Methods for the Decade of Vaccines

Edited by: F Bagnoli, R Rappuoli (2015)

www.caister.com/vaccines

- Antifungals: From Genomics to Resistance and the Development of Novel Agents

Edited by: AT Coste, P Vandeputte (2015)

www.caister.com/antifungals

- Bacteria-Plant Interactions: Advanced Research and Future Trends Edited by: J Murillo, BA Vinatzer, RW Jackson, et al. (2015) www.caister.com/bacteria-plant

\section{- Aeromonas}

Edited by: J Graf (2015)

www.caister.com/aeromonas

- Antibiotics: Current Innovations and Future Trends

Edited by: S Sánchez, AL Demain (2015)

www.caister.com/antibiotics

- Leishmania: Current Biology and Contro Edited by: S Adak, R Datta (2015) www.caister.com/leish2

- Acanthamoeba: Biology and Pathogenesis (2nd edition) Author: NA Khan (2015)

www.caister.com/acanthamoeba2

- Microarrays: Current Technology, Innovations and Applications Edited by: Z He (2014)

www.caister.com/microarrays2

- Metagenomics of the Microbial Nitrogen Cycle: Theory, Methods and Applications

Edited by: D Marco (2014)

www.caister.com/n2 